\title{
ANALISIS SIFAT KIMIA AIR TANAH SUMUR DANGKAL PADA TANAH BERKAPUR (DESA GAMPING KECAMATAN CAMPURDARAT KABUPATEN TULUNGAGUNG)
}

\author{
Emma Yuliani $^{1}$, Dea Rozan Aqil Pradana ${ }^{2}$ \\ ${ }^{1}$ Mahasiswa Program Sarjana Teknik Pengairan Universitas Brawijaya \\ ${ }^{2}$ Dosen Teknik Pengairan Fakultas Teknik Universitas Brawijaya \\ Teknik Pengairan Universitas Brawijaya-Malang, Jawa Timur, Indonesia \\ Jalan MT. Haryono 167 Malang 65145, Indonesia \\ ${ }^{1}$ Email: emma_yuliani80@yahoo.com
}

\begin{abstract}
ABSTRAK: Air tanah merupakan salah satu dari sekian banyak alternatif sumber air yang mempunyai kuantitas maupun kualitas yang tergolong besar dan sangat baik. Faktor penting yang harus di perhatikan dalam pengelolaan air tanah adalah analisa sifat kimianya. Sifat kimia tersebut akan memberikan dampak yang besar bagi obyek yang menerima dan mengkonsumsi air tanah secara berkala. Tujuan dari penelitian ini adalah untuk mengetahui efek terjadinya rsiko terhadap obyek yang menerima dan mengetahui sifat kimia air tanah yang ada pada lokasi penelitian. Untuk mengetahui efek terjadinya resiko pada lokasi penelitian, menggunakan persamaan yang dianjurkan oleh EPA (Environmental Protection Agency). Analisis sifat kimia air tanah dilakukan dengan menggunakan Metode Diagram Pie, Metode Kurlov. Dari hasil penelitian yang dilakukan pada Desa Gamping Kecamatan Campurdarat Kabupaten Tulungagung diketahui bahwa air tanah lokasi penelitian mempunyai faktor resiko terhadap kesehatan dan didominasi oleh kandungan anion bikarbonat dan kation kalsium, natrium .
\end{abstract}

Kata kunci: resiko, sifat kimia, air tanah, diagram pie, kurlov

ABSTRACT: Groundwater is one of the many alternative water sources that have a large and very good quantity and quality. An important factor that must be considered in groundwater management is the analysis of its chemical characteristics. These chemical characteristics will have a large impact on objects that receive and consume ground water regularly. The purpose of this study was to determine the effect of the risk of the object receiving and knowing the chemical characteristics of groundwater in the study location. To find out the effect of the occurrence of risk on the research location, use the equation recommended by the EPA (Environmental Protection Agency). Analysis of the chemical characteristics of groundwater was carried out using the Pie Chart Method, and the Kurlov Method. From the results of research conducted in Gamping Village, Campurdarat District, Tulungagung Regency, it is known that the groundwater in the study site has health risk factors and is dominated by anion bicarbonate $\left(\mathrm{HCO}_{3}^{-}\right)$, and kation calcium, sodium.

Keywords: risk, chemical characteristics, groundwater, pie chart, kurlov

\section{PENDAHULUAN}

Air tanah merupakan kebutuhan yang diperlukan untuk masyarakat. Bertambahnya jumlah penduduk dan seiring dengan kebutuhan yang semakin besar, menjadikan kualitas air tanah sangatlah perlu untuk dipelihara dan dijaga. Daerah Tulungagung merupakan daerah yang mempunyai jajaran pegunungan yang terletak di selatan yang memiliki komposisi kapur yang lama kelamaan berubah menjadi batu marmer. Marmer adalah batu pualam, metamorfosis batu kapur atau dolomit yang mengalami proses perubahan tekanan dan temperatur selama ratusan tahun. 
Batu marmer yang ada di Indonesia diperkirakan berusia antara 30 hingga 60 juta tahun. Kabupaten Tulungagung sendiri usaha penambangan marmer banyak ditemukan di Kecamatan Campurdarat dan Kecamatan Besuki. Khususnya pada Kecamatan Campurdarat pada Desa Gamping terkenal akan industri marmer yang mengakibatkan munculnya pertambangan dimana-mana. Mereka bekerja untuk perusahaan-perusahaan penambang ataupun insiatif sendiri.

Pada penelitian ini lokasi berada pada Desa Gamping Kecamatan Campur Darat, Kabupaten Tulungagung Jawa Timur. Letak geografis Kabupaten Tulungagung adalah $111^{\circ} 45^{\prime}-112,07^{\circ} \mathrm{BT}$ dan $7,51^{\circ}-8,08^{\circ} \mathrm{LS}$. Kabupaten Tulungagung terkenal sebagai salah satu dari beberapa daerah penghasil marmer terbesar di Indonesia, dan terletak $154 \mathrm{~km}$ barat daya Kota Surabaya, ibu kota Provinsi Jawa Timur. Kabupaten Tulungagung terletak pada ketinggian $85 \mathrm{~m}$ diatas permukaan laut (dpl). Bagian barat Kabupaten Tulungagung merupakan daerah pegunungan yang merupakan bagian dari gunung Wilis- Liman. Bagian tengah adalah dataran rendah, sedangkan bagian selatan adalah pegunungan yang merupakan rangkaian dari Pegunungan Kidul. Di sebelah barat laut Tulungagung, tepatnya di Kecamatan Sendang, terdapat Gunung Wilis sebagai titik tertinggi di Kabupaten Tulungagung yang memiliki ketinggian $2552 \mathrm{~m}$.

Studi ini bertujuan untuk: (1) Bagaimana parameter fisik (suhu, kekeruhan) dan kimia (pH, $\mathrm{Na}+, \mathrm{Mg} 2+, \mathrm{Ca} 2+, \mathrm{K}+, \mathrm{Cl}-, \mathrm{HCO} 3-$, CO32-, SO42-, Fe) pada kualitas air tanah dangkal (sumur) di Desa Gamping Kecamatan Campurdarat, Kabupaten Tulungagung. (2) Bagaimana status mutu air minum perdasarkan Peraturan Kementrian Kesehatan Nomer 492/Menkes/Per/IV/2010 dan bagaimana tingkat analisa resiko terhadap evaluasi asupan kontaminan yang masuk kedalam tubuh manusia di daerah penelitian. (3) Bagaimana karakteristik kimia air tanah sumur dangkal di daerah penelitian terdahulu.

\section{Kelayakan Kualitas air}

Dampak dari adanya penyimpangan standar kualitas air, berdampak pada kesehatan masyarakat langsung maupun tidak langsung. Berdasarkan Peraturan Mentri Kesehatan RI Nomer 492 Tahun 2010 tentang Persyaratan Kualitas Air Minum.
Untuk mengetahui lebih lanjut terhadap penelitian ini, penentuan kondisi kualitas air ditentukan oleh Peraturan Kementerian Kesehatan Nomer 492/Menkes/Per/IV/2010 tentang Persyaratan Kualitas Air Minum.

\section{Analisa Resiko}

Analisis resiko adalah penentuan probabilitas dan besarnya efek buruk dengan konsekuensi tertentu yang terjadi pada penggunaan dan nilai-nilai yang menguntungkan dalam jangka waktu tertentu (Suter, 1993, Hart et al., 2005 dalam Yuliani 2014: 19).

Sarana analisis yang diperlukan akan bervariasi pada kasus-per kasus. Pendekatan bertahap untuk analisis resiko dapat diambil, dimulai dengan analisis sederhana dan kemudian meningkat yang lebih kompleks disesuaikan dengan kebutuhan yang diperlukan (Yuliani 2014: 19)

\section{Analisis Resiko Akibat Kontaminan}

Menurut Yuliani (2014 :27), kontaminan yang terkandung dalam tanah dan air tanah terutama yang dikategorikan sebagai buangan beracun dan berbahaya mempunyai potensi dalam menyebabkan gangguan pada manusia dan lingkungan. Seringkali kontaminan dalam tanah dan air tanah terdapat dalam konsentrasi yang rendah dan sulit dideteksi, sehingga tidak disadari paparan yang menerus tersebut mengakibatkan gangguan kesehatan yang baru timbul setelah bertahun-tahun.

\section{Evaluasi Terhadap Kontaminan}

Menurut Notodarmojo (2005: 178), paparan kontaminan bila terjadi pada siapa saja dengan efek pada kesehatan yang tak terduga. Untuk memperkirakan seberapa besar paparan tersebut, frekuensi serta lamanya paparan dan rute paparan, maka diperlukannya evaluasi. Dalam hal ini paparan kontaminan tanah dan air tanah, rute kontaminan yang masuk pada manusia sebagian besar melalui mulut (minum dan makan).

Salah satu faktor penting dalam elevasi paparan kontaminan adalah bagaimana memperkirakan jumlah kontaminan yang masuk ke dalam tubuh manusia atau terpapar pada manusia. Persamaan umum untuk menghitung asupan kontaminan yang dianjurkan oleh EPA adalah sebagai berikut (Watt, 1998 dalam Notodarmojo, 2005: 178) 

air tanah :

Untuk kontaminan yang terlarut dalam

$\mathrm{I}=\frac{C \times I R \times F P \times W P}{B T} \times \frac{1}{W R}$

Dimana :

I : Intake atau asupan kontaminan harian (mg/kg- hari)

C : konsentrasi kontaminan rata rata selama periode pengamatan $(\mathrm{mg} / \mathrm{L}$ untuk kontaminan air atau $\mathrm{mg} / \mathrm{m} 3$ untuk kontaminan dari udara)

IR : jumlah medium yang tertelan persatuan waktu (L/hari)

FP : frekuansi paparan (hari/tahun)

WP : lama waktu paparan (tahun)

BT : berat tubuh yang terpapar $(\mathrm{kg})$

WR : waktu perata, dimana paparan dirataratakan (hari)

Setalah ini asupan kontaminan (I) diketahui, selanjutnya menghitung indeks gangguan (HI) dengan persamaan:

$\mathrm{HI}=\mathrm{I} / \mathrm{RfD}$

Apabila HI $<1$, maka tidak terjadi resiko pada kesehatannya dan $\mathrm{HI}>1$, terjadi resiko pada kesehatannya.

Tabel 1. Nilai RfD dan Sf untuk beberapa kontaminan terpilih

\begin{tabular}{|l|l|l|l|l|l|l|l}
\hline No & \multicolumn{1}{|c|}{ Kontaminan } & RfD & SF & No & \multicolumn{1}{|c}{ Kontaminan } & RfD & SF \\
\hline 1 & Benzene & - & 0,029 & 14 & DDT & $5 \times 10^{-4}$ & 0,34 \\
\hline 2 & Toluene & 0,2 & - & 15 & Hexachlorobenze & $8 \times 10^{-4}$ & 1,6 \\
\hline 3 & Etilbenzene & 0,1 & - & 16 & Lindane & $3 \times 10^{-4}$ & - \\
\hline 4 & Xylene & 2 & - & 17 & Fluorene (Child) & 0,093 & - \\
\hline 5 & Anthracen & 0,3 & - & 18 & Antrazine & 0,035 & - \\
\hline 6 & Fluorene & 0,04 & - & 19 & Phenol & 0,6 & - \\
\hline 7 & Pyrene & 0,03 & - & 20 & Arzine (anorganik) & $3 \times 10^{-4}$ & 1,5 \\
\hline 8 & Acetone & 0,1 & - & 21 & Boron & 0,09 & - \\
\hline 9 & Metil etil ketone & 0,6 & - & 22 & Cadmium & $5 \times 10^{-4}$ & - \\
\hline 10 & Aldrin & $3 \times 10^{-5}$ & 17 & 23 & Chromium (VI) & 0,005 & - \\
\hline 11 & Cabaryl & 0,1 & - & 24 & Tembega sianida & 0,005 & - \\
\hline 12 & Dieldrin & $5 \times 10^{-5}$ & 16 & 25 & Mangan & 0,005 & - \\
\hline 13 & Chloride (grow) & 0,204 & - & 26 & Sulfate (Grow) & 0,408 & - \\
\hline 14 & Chloride (child) & 0,476 & - & 27 & Sulfate (Child) & 0,95 & - \\
\hline
\end{tabular}

Sumber : Notodarmojo (dalam EPA 1995), (2005: 176)

\section{Metode Diagram Pie}

Metode diagram ini merupakan diagram lingkaran untuk menganalisa komposisi kandungan kimia dalam sumur air tanah yang dinyatakan dengan besar jari- jari pada diagram lingkaran. Didalam satu lingkaran akan dibagi besaran potongan yang berbeda beda luasannya berdasarkan jumlah kandungan unsur yang terdapat pada sampel air tanah. Setiap sumur air tanah akan manghasilkan nilai diagram yang berbeda-beda targantung dari besarnya kandungan sempel air tanah dangkal (Todd, 1980: 286).
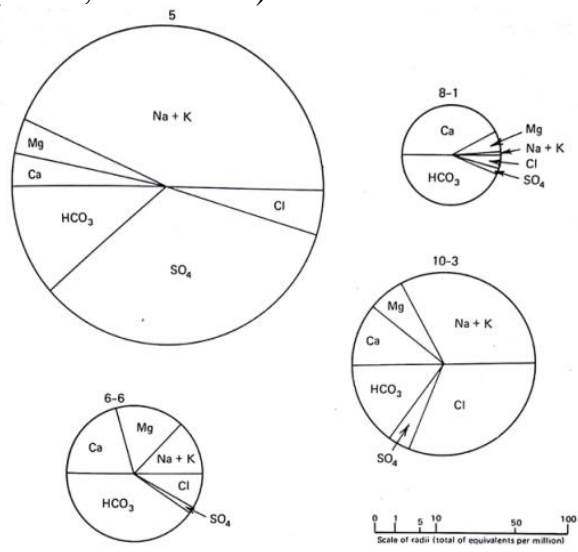

Gambar 1. Diagram Pie

Sumber :Todd, (1980)

\section{Metode Kurlov}

Metode kurlov sangat praktis dan dengan cepat dapat menentukan kelas alirannya. Penamaan kelas aliran air tanah di tentukan oleh kandungan ion yang mempunyai jumlah prosentasenya $\geq 25 \%$ (Suharyadi, 1984) dalam (Kristanto, D.D 2015, p.32). Dalam Metode Klasifikasi Kurlov antara anion dan kation dari berbagai sampel disajikan dalam sebuah tabel. Untuk mengetahui perbandingan antara jumah masing-masing ion yang terkandung dalam larutan, maka satuan $\mathrm{mg} / \mathrm{liter}$ harus dikonversikan kedalam satuan mq/liter (epj).

Cara mengkonversikan satuan $\mathrm{mg} / \mathrm{liter}$ menjadi apj :

Jumlah ekuivalen unsu $=\frac{\text { Berat Atom Unsur }}{\text { Valensi }}$

Kandungan unsur $(\mathrm{epj})=$

Kandungan Unsur (mg/liter)

Tahapan analisis penamaan kandungan air tanah dengan menggunakan Metode Klasifikasi Kurlov adalah sebagai berikut:

1. Data dari hasil uji laboratorium diubah menjadi satuan epj.

2. Antara kation dan anion dipisah kemudian menjadi satuan persen.

3. Pembarian nama tipe jenis kandungan air, berdasarkan kandungan dengan prosentase $25 \%$.

\section{METODOLOGI}

Lokasi studi berada pada Desa Gamping

Kecamatan Campur Darat, Kabupaten Tulungagung Jawa Timur. Letak geografis 
Kabupaten Tulungagung adalah $111^{\circ} 45^{\prime}$ $112,07^{\circ} \mathrm{BT}$ dan $7,51^{\circ}-8,08^{\circ} \mathrm{LS}$.

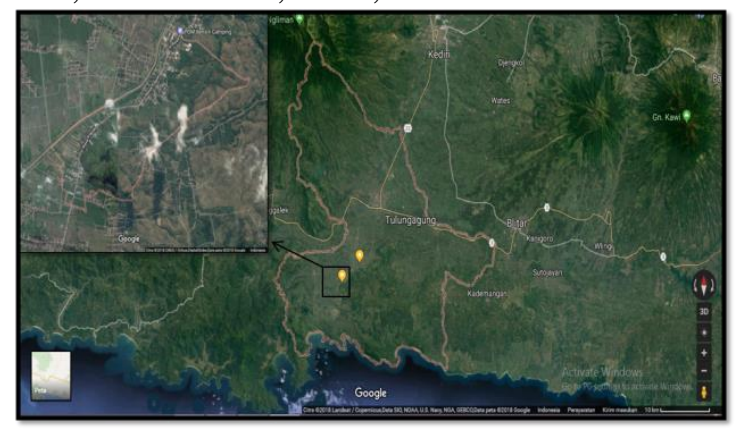

Gambar 2. Peta lokasi Desa Gamping Kecamatan Campurdarat Kabupaten Tulungagung

Sumber : Google Earth, 2018

Berdasarkan Peta Rupa Bumi (RBI) maka diperjelas batas wilayah dan juga lokasi titik pengambilan sampel sebagai berikut :

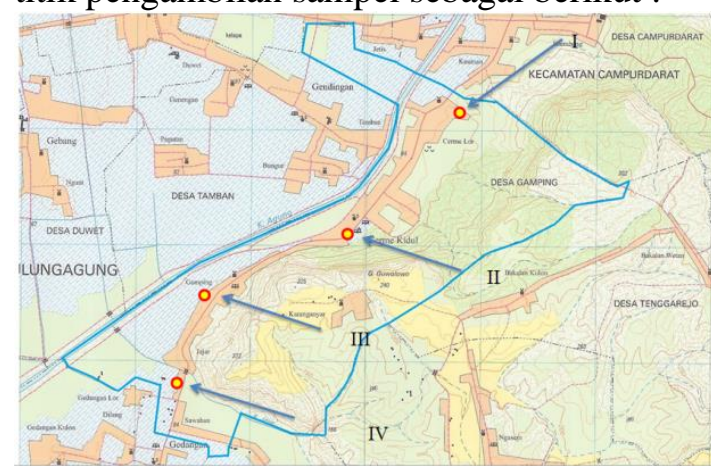

Gambar 3. Lokasi Titik Pengambilan Sampel Sumber : Pata Rupa Bumi

\section{Data Yang Diperlukan}

Data-data yang dibutuhkan untuk menyelesaikan penelitian ini adalah sebagai berikut :

A. Data Primer

1. Sampel Air

B. Data Sekunder

1. Peta Rupa Bumi

2. Peta Batas Wilayah

3. Peta Geologi

4. Data Standar Baku Mutu Persyaratan Kualisa Air Minum

5. Form Data Lapangan

\section{Langkah Pengerjaan Studi}

Alur studi penelitian ini mengikuti langkah-langkah sebagai berikut:

1. Melakukan survei lapangan sesuai dengan peta yang talah didapatkan dengan bantuan Global Position Satelite (GPS) untuk mengetahui dan menentukan titik pengambilan sampel air tanah yang berupa sumur gali penduduk.

2. Pengambilan sampel air tanah pada lokasi studi sesuai pada langkah (1) dengan metode purposiv sampling dan sesuai dengan SNI 6989.58: 2008

3. Pengujian laboratorium sampel air yang telah diambil guna mengetahui parameter $\mathrm{pH}, \mathrm{Na}+, \mathrm{Mg}^{2+}, \mathrm{Ca}^{2+}, \mathrm{K}^{+}, \mathrm{Cl}^{-}, \mathrm{HCO}_{3}{ }^{-}, \mathrm{CO}_{3}{ }^{2-}$ $, \mathrm{SO}_{4}{ }^{2-}, \mathrm{Fe}$

4. Data hasil uji laboratorium kemudian di interpretasikan kedalam Peraturan Kemenentrian Kesehatan Nomer 492/Menkes/Per/IV/2010 tentang Persyaratan Kualitas Air Minum. Untuk mengetahui baku mutunya.

5. Menganalisa faktor resiko terhadap kesehatan sesuai dengan menggunakan persanaan yang dianjurkan oleh Environmental Protection Agency (EPA) dan dari buku Notodarmojo, 2005.

6. Data hasil laboratorium dianalisa dengan menggunakan Metode Diagram Pie, dan Metode Kurlov pada tanggal 27 april 2018

HASIL DAN PEMBAHASAN

Kelayakan Status Keamanan Mutu Air

Tabel 2. Rekapitulasi Klasifikasi Mutu Air

\begin{tabular}{|c|c|c|c|c|c|c|c|}
\hline \multirow{2}{*}{ Parmeter } & \multirow{2}{*}{ Satuan } & \multicolumn{4}{|c|}{ Sumur } & \multirow{2}{*}{$\begin{array}{c}\text { Kadar } \\
\text { Maksimu } \\
\text { m } \\
\end{array}$} & \multirow[b]{2}{*}{ atus Mutu Air } \\
\hline & & 1 & 2 & 3 & 4 & & \\
\hline $\mathrm{pH}$ & & 5,79 & 6,27 & 6,34 & 6,25 & $6,5-8,5$ & $\begin{array}{l}\text { Semua Sumur } \\
\text { Tidak Aman }\end{array}$ \\
\hline Kekeruhan & NTU & 23,1 & 3,3 & 11,3 & 4,3 & 5 & $\begin{array}{c}\text { Sumur } 2,4 \\
\text { Aman } \\
\text { Sumur } 1,3 \\
\text { Tidak Aman }\end{array}$ \\
\hline Suhu & ${ }^{\circ} \mathrm{C}$ & 27,64 & 27,43 & 27,25 & 27,6 & $\begin{array}{c}\text { Suhu } \\
\text { udara } \pm 3\end{array}$ & $\begin{array}{l}\text { Semua Sumur } \\
\text { Aman }\end{array}$ \\
\hline $\mathrm{Na}^{+}$ & $(\mathrm{mg} / \mathrm{l})$ & 25,86 & 29,86 & 35,00 & 35,93 & $200 \mathrm{ml} / \mathrm{g}$ & $\begin{array}{c}\text { Semua Sumur } \\
\text { Aman }\end{array}$ \\
\hline $\mathrm{Mg}^{2+}$ & $(\mathrm{mg} / \mathrm{l})$ & 29,81 & 24,32 & 16,53 & 28,23 & $0,4 \mathrm{ml} / \mathrm{g}$ & $\begin{array}{l}\text { Semua Sumur } \\
\text { Tidak Aman }\end{array}$ \\
\hline $\mathrm{Ca}^{2+}$ & $(\mathrm{mg} / \mathrm{l})$ & 41,58 & 48,93 & 27,41 & 32.62 & $200 \mathrm{ml} / \mathrm{g}$ & $\begin{array}{c}\text { Semua Sumur } \\
\text { Aman }\end{array}$ \\
\hline $\mathrm{Cl}^{-}$ & $(\mathrm{mg} / \mathrm{l})$ & 49,403 & 34,202 & 55,103 & 39,903 & $250 \mathrm{ml} / \mathrm{g}$ & $\begin{array}{c}\text { Semua Sumur } \\
\text { Aman }\end{array}$ \\
\hline $\mathrm{SO}_{4}{ }^{-}$ & $(\mathrm{mg} / \mathrm{l})$ & 18,023 & 20,93 & 14,535 & 19,767 & $250 \mathrm{ml} / \mathrm{g}$ & $\begin{array}{c}\text { Semua Sumur } \\
\text { Aman }\end{array}$ \\
\hline $\mathrm{Fe}$ & $(\mathrm{mg} / \mathrm{l})$ & 0,103 & 1,022 & 0,31 & 0,181 & $0,3 \mathrm{ml} / \mathrm{g}$ & $\begin{array}{c}\text { Sumur } 1,4 \\
\text { Aman } \\
\text { Sumur } 2,3 \\
\text { Tidak Aman }\end{array}$ \\
\hline
\end{tabular}

Sumber :Hasil Analisa dengan Peraturan Kementrian Kesehatan Nomer 492/Menkes/Per/IV/2010

Dari Tabel 2 dijelaskan rekapitulasi analisa status mutu air. Dari beberapa parameter menunjukan bahwa ada beberapa kandungan kimia mempunyai status tidak aman untuk di konsumsi namun ada juga yang masih dibawah batas maksimun dan menunjukkan status mutunya aman.

\section{Evaluasi Terhadap Paparan Kontaminan}

Perhitungan analisa resiko kandungan kimia terhadap manusia dengan menggunakan 
parameter yeng telah di tentukan. Faktor-faktor perhitungan asupan analisa resiko untuk kebutuhan air minum yang telah di tentukan oleh EPA (Enviromental Protection Agency).

Sumur 1

Tabel 3. Perhitungan analisa Resiko Dengan Parameter $\mathrm{Cl}^{-}$(Klorida)

\begin{tabular}{|c|c|c|c|c|c|c|c|c|c|c|}
\hline \multirow{2}{*}{ Konsumsi } & $\mathrm{C}$ & IR & FP & $\begin{array}{l}\text { W } \\
P\end{array}$ & $\begin{array}{l}B \\
T\end{array}$ & WR & I & RfD & HI & \multirow{2}{*}{$\begin{array}{c}\text { Resik } \\
0\end{array}$} \\
\hline & $\begin{array}{c}\mathrm{mg} / \mathrm{l} \\
\text { iter }\end{array}$ & $\begin{array}{l}\text { liter/ } \\
\text { hari }\end{array}$ & $\begin{array}{c}\text { hari/ta } \\
\text { hun }\end{array}$ & $\begin{array}{l}\text { tah } \\
\text { un }\end{array}$ & $\begin{array}{l}\mathrm{K} \\
\mathrm{g}\end{array}$ & $\begin{array}{c}\mathrm{Har} \\
\mathrm{i}\end{array}$ & $\begin{array}{c}\mathrm{mg} / \mathrm{kg}- \\
\text { hari }\end{array}$ & $\begin{array}{c}\mathrm{mg} / \mathrm{kg}- \\
\text { hari }\end{array}$ & $\begin{array}{c}\mathrm{mg} / \mathrm{kg}- \\
\text { hari }\end{array}$ & \\
\hline $\begin{array}{c}\text { Dewasa (BT } \\
=70 \mathrm{Kg})\end{array}$ & $\begin{array}{c}49,4 \\
03\end{array}$ & 2 & 365 & 30 & $\begin{array}{l}7 \\
0\end{array}$ & $\begin{array}{c}109 \\
50\end{array}$ & 1,412 & 0,204 & 6,919 & $\begin{array}{c}\text { Beres } \\
\text { iko }\end{array}$ \\
\hline $\begin{array}{c}\text { Dewasa (BT } \\
=55 \mathrm{Kg})\end{array}$ & $\begin{array}{c}49,4 \\
03\end{array}$ & 2 & 365 & 30 & $\begin{array}{l}5 \\
5\end{array}$ & $\begin{array}{l}109 \\
50\end{array}$ & 1,796 & 0,204 & 8,806 & $\begin{array}{c}\text { Beres } \\
\text { iko }\end{array}$ \\
\hline Aanak -anak & $\begin{array}{c}49,4 \\
03\end{array}$ & 1 & 365 & 6 & $\begin{array}{l}1 \\
5\end{array}$ & $\begin{array}{c}219 \\
0\end{array}$ & 3,294 & 0,204 & 16,145 & $\begin{array}{c}\text { Beres } \\
\text { iko }\end{array}$ \\
\hline
\end{tabular}

Sumber : Hasil Analisa

Tabel 4. Perhitungan analisa Resiko Dengan Parameter $\mathrm{SO}_{4}^{-}$(Sulfat)

\begin{tabular}{|c|c|c|c|c|c|c|c|c|c|c|}
\hline \multirow{2}{*}{ Konsumsi } & C & IR & FP & $\begin{array}{l}\text { W } \\
P\end{array}$ & $\begin{array}{l}\mathrm{B} \\
\mathrm{T}\end{array}$ & WR & I & RfD & HI & \multirow{2}{*}{$\begin{array}{c}\text { Resik } \\
0\end{array}$} \\
\hline & $\begin{array}{l}\mathrm{mg} / \mathrm{l} \\
\text { iter }\end{array}$ & $\begin{array}{l}\text { liter/ } \\
\text { hari }\end{array}$ & $\begin{array}{c}\text { hari/ta } \\
\text { hun }\end{array}$ & $\begin{array}{l}\text { tah } \\
\text { un }\end{array}$ & $\begin{array}{l}\text { K } \\
\mathrm{g}\end{array}$ & $\begin{array}{c}\mathrm{Har} \\
\mathrm{i}\end{array}$ & $\begin{array}{c}\mathrm{mg} / \mathrm{kg}- \\
\text { hari }\end{array}$ & $\begin{array}{c}\mathrm{mg} / \mathrm{kg}- \\
\text { hari }\end{array}$ & $\begin{array}{l}\mathrm{mg} / \mathrm{kg}- \\
\text { hari }\end{array}$ & \\
\hline $\begin{array}{c}\text { Dewasa (BT } \\
=70 \mathrm{Kg})\end{array}$ & $\begin{array}{c}18,0 \\
23\end{array}$ & 2 & 365 & 30 & $\begin{array}{l}7 \\
0\end{array}$ & $\begin{array}{c}109 \\
50\end{array}$ & 0,515 & 0,408 & 1,262 & $\begin{array}{c}\text { Beres } \\
\text { iko }\end{array}$ \\
\hline $\begin{array}{c}\text { Dewasa (BT } \\
=55 \mathrm{Kg})\end{array}$ & $\begin{array}{l}18,0 \\
23\end{array}$ & 2 & 365 & 30 & $\begin{array}{l}5 \\
5\end{array}$ & $\begin{array}{c}109 \\
50\end{array}$ & 0,655 & 0,408 & 1,606 & $\begin{array}{c}\text { Beres } \\
\text { iko }\end{array}$ \\
\hline Aanak -anak & $\begin{array}{c}18,0 \\
23\end{array}$ & 1 & 365 & 6 & $\begin{array}{l}1 \\
5\end{array}$ & $\begin{array}{c}219 \\
0\end{array}$ & 1,202 & 0,408 & 2,945 & $\begin{array}{c}\text { Beres } \\
\text { iko }\end{array}$ \\
\hline
\end{tabular}

Sumber: Hasil Analisa

Tabel 5. Perhitungan analisa Resiko Dengan Parameter $\mathrm{Mg}^{2+}$ (Mangan)

\begin{tabular}{|c|c|c|c|c|c|c|c|c|c|c|}
\hline \multirow{2}{*}{ Konsumsi } & $\mathrm{C}$ & IR & FP & $\begin{array}{l}\text { W } \\
P\end{array}$ & $\begin{array}{l}\mathrm{B} \\
\mathrm{T}\end{array}$ & WR & I & RfD & HI & \multirow{2}{*}{$\begin{array}{c}\text { Resik } \\
0\end{array}$} \\
\hline & $\begin{array}{l}\mathrm{mg} / \mathrm{l} \\
\text { iter }\end{array}$ & $\begin{array}{l}\text { liter/ } \\
\text { hari }\end{array}$ & $\begin{array}{c}\text { hari/ta } \\
\text { hun }\end{array}$ & $\begin{array}{l}\text { tah } \\
\text { un }\end{array}$ & $\begin{array}{l}\mathrm{K} \\
\mathrm{g}\end{array}$ & $\begin{array}{c}\mathrm{Har} \\
\mathrm{i}\end{array}$ & $\begin{array}{c}\mathrm{mg} / \mathrm{kg}- \\
\text { hari }\end{array}$ & $\begin{array}{c}\mathrm{mg} / \mathrm{kg}- \\
\text { hari }\end{array}$ & $\begin{array}{c}\mathrm{mg} / \mathrm{kg}- \\
\text { hari }\end{array}$ & \\
\hline $\begin{array}{c}\text { Dewasa (BT } \\
=70 \mathrm{Kg} \text { ) }\end{array}$ & $\begin{array}{c}29.8 \\
1\end{array}$ & 2 & 365 & 30 & $\begin{array}{l}7 \\
0\end{array}$ & $\begin{array}{l}109 \\
50\end{array}$ & 0.852 & 0.005 & $\begin{array}{c}170.34 \\
3\end{array}$ & $\begin{array}{c}\text { Beres } \\
\text { iko }\end{array}$ \\
\hline $\begin{array}{c}\text { Dewasa (BT } \\
=55 \mathrm{Kg})\end{array}$ & $\begin{array}{c}29.8 \\
1\end{array}$ & 2 & 365 & 30 & $\begin{array}{l}5 \\
5\end{array}$ & $\begin{array}{c}109 \\
50\end{array}$ & 1.084 & 0.005 & $\begin{array}{c}216.80 \\
0\end{array}$ & $\begin{array}{c}\text { Beres } \\
\text { iko }\end{array}$ \\
\hline Aanak -anak & $\begin{array}{c}29.8 \\
1\end{array}$ & 1 & 365 & 6 & $\begin{array}{l}1 \\
5\end{array}$ & $\begin{array}{c}219 \\
0\end{array}$ & 1.987 & 0.005 & $\begin{array}{c}397.46 \\
7\end{array}$ & $\begin{array}{c}\text { Beres } \\
\text { iko }\end{array}$ \\
\hline
\end{tabular}

Sumber : Hasil Analisa

Tabel 6. Perhitungan analisa Resiko Dengan Parameter Fe (Besi)

\begin{tabular}{|c|c|c|c|c|c|c|c|c|c|c|}
\hline \multirow{2}{*}{ Konsumsi } & $\mathrm{C}$ & $\mathrm{IR}$ & FP & $\begin{array}{l}\text { W } \\
P\end{array}$ & $\begin{array}{l}\text { B } \\
\text { T }\end{array}$ & $\begin{array}{l}\mathrm{W} \\
\mathrm{R}\end{array}$ & I & RfD & $\mathrm{HI}$ & \multirow{2}{*}{ Resiko } \\
\hline & $\begin{array}{l}\mathrm{mg} / \mathrm{l} \\
\text { iter }\end{array}$ & $\begin{array}{l}\text { liter/ } \\
\text { hari }\end{array}$ & $\begin{array}{l}\text { hari/t } \\
\text { ahun }\end{array}$ & $\begin{array}{l}\text { tah } \\
\text { un }\end{array}$ & $\begin{array}{l}\mathrm{K} \\
\mathrm{g}\end{array}$ & $\begin{array}{c}\text { Har } \\
\mathrm{i}\end{array}$ & $\begin{array}{c}\mathrm{mg} / \mathrm{kg} \\
\text {-hari }\end{array}$ & $\begin{array}{c}\mathrm{mg} / \mathrm{kg} \\
\text {-hari }\end{array}$ & $\begin{array}{c}\mathrm{mg} / \mathrm{kg} \\
\text {-hari }\end{array}$ & \\
\hline $\begin{array}{c}\text { Dewasa (BT } \\
=70 \mathrm{Kg})\end{array}$ & $\begin{array}{c}0,10 \\
3\end{array}$ & 2 & 365 & 30 & $\begin{array}{l}7 \\
0\end{array}$ & $\begin{array}{c}109 \\
50\end{array}$ & 0,003 & 0,7 & 0,004 & $\begin{array}{c}\text { Tidak } \\
\text { beresiko }\end{array}$ \\
\hline $\begin{array}{l}\text { Dewasa (BT } \\
=55 \mathrm{Kg})\end{array}$ & $\begin{array}{c}0,10 \\
3\end{array}$ & 2 & 365 & 30 & $\begin{array}{l}5 \\
5\end{array}$ & $\begin{array}{c}109 \\
50\end{array}$ & 0,004 & 0,7 & 0,005 & $\begin{array}{c}\text { Tidak } \\
\text { beresiko }\end{array}$ \\
\hline Aanak -anak & $\begin{array}{c}0,10 \\
3\end{array}$ & 1 & 365 & 6 & $\begin{array}{l}1 \\
5\end{array}$ & $\begin{array}{c}219 \\
0\end{array}$ & 0,007 & 0,7 & 0,010 & $\begin{array}{c}\text { Tidak } \\
\text { beresiko }\end{array}$ \\
\hline
\end{tabular}

Sumber: Hasil Analisa

Tabel 7. Perhitungan analisa Resiko Dengan Parameter $\mathrm{Na}^{+}$(Natrium)

\begin{tabular}{|c|c|c|c|c|c|c|c|c|c|c|}
\hline \multirow{2}{*}{ Konsumsi } & $\mathrm{C}$ & IR & FP & $\begin{array}{l}\text { W } \\
P\end{array}$ & $\begin{array}{l}\mathrm{B} \\
\mathrm{T}\end{array}$ & WR & I & RfD & $\mathrm{HI}$ & \multirow{2}{*}{$\begin{array}{c}\text { Resik } \\
0\end{array}$} \\
\hline & $\begin{array}{l}\mathrm{mg} / \mathrm{l} \\
\text { iter }\end{array}$ & $\begin{array}{l}\text { liter/ } \\
\text { hari }\end{array}$ & $\begin{array}{c}\text { hari/ta } \\
\text { hun }\end{array}$ & $\begin{array}{l}\text { tah } \\
\text { un }\end{array}$ & $\begin{array}{l}\mathrm{K} \\
\mathrm{g}\end{array}$ & $\begin{array}{c}\text { Har } \\
\mathrm{i}\end{array}$ & $\begin{array}{c}\mathrm{mg} / \mathrm{kg}- \\
\text { hari }\end{array}$ & $\begin{array}{c}\mathrm{mg} / \mathrm{kg}- \\
\text { hari }\end{array}$ & $\begin{array}{c}\mathrm{mg} / \mathrm{kg}- \\
\text { hari }\end{array}$ & \\
\hline $\begin{array}{c}\text { Dewasa (BT } \\
=70 \mathrm{Kg} \text { ) }\end{array}$ & $\begin{array}{c}25.8 \\
6\end{array}$ & 2 & 365 & 30 & $\begin{array}{l}7 \\
0\end{array}$ & $\begin{array}{c}109 \\
50\end{array}$ & 0.739 & 0.03 & 24.629 & $\begin{array}{c}\text { Beres } \\
\text { iko }\end{array}$ \\
\hline $\begin{array}{c}\text { Dewasa (BT } \\
=55 \mathrm{Kg} \text { ) }\end{array}$ & $\begin{array}{c}25.8 \\
6\end{array}$ & 2 & 365 & 30 & $\begin{array}{l}5 \\
5\end{array}$ & $\begin{array}{c}109 \\
50\end{array}$ & 0.940 & 0.03 & 31.345 & $\begin{array}{c}\text { Beres } \\
\text { iko }\end{array}$ \\
\hline Aanak -anak & $\begin{array}{c}25.8 \\
6 \\
\end{array}$ & 1 & 365 & 6 & $\begin{array}{l}1 \\
5\end{array}$ & $\begin{array}{c}219 \\
0 \\
\end{array}$ & 1.724 & 0.03 & 57.467 & $\begin{array}{c}\text { Beres } \\
\text { iko }\end{array}$ \\
\hline
\end{tabular}

Sumber : Hasil Analisa

Tabel 8. Perhitungan analisa Resiko Dengan Parameter $\mathrm{K}^{+}$(Kalium)

\begin{tabular}{|c|c|c|c|c|c|c|c|c|c|c|}
\hline \multirow{2}{*}{ Konsumsi } & C & IR & FP & $\begin{array}{l}\text { W } \\
\text { P }\end{array}$ & $\begin{array}{l}\mathrm{B} \\
\mathrm{T}\end{array}$ & WR & I & RfD & HI & \multirow{2}{*}{$\begin{array}{c}\text { Resik } \\
0\end{array}$} \\
\hline & $\begin{array}{c}\mathrm{mg} / \mathrm{l} \\
\text { iter }\end{array}$ & $\begin{array}{l}\text { liter/ } \\
\text { hari }\end{array}$ & $\begin{array}{c}\text { hari/ta } \\
\text { hun }\end{array}$ & $\begin{array}{l}\text { tah } \\
\text { un }\end{array}$ & $\begin{array}{l}\mathrm{K} \\
\mathrm{g}\end{array}$ & $\begin{array}{c}\mathrm{Har} \\
\mathrm{i}\end{array}$ & $\begin{array}{c}\mathrm{mg} / \mathrm{kg}- \\
\text { hari }\end{array}$ & $\begin{array}{c}\mathrm{mg} / \mathrm{kg}- \\
\text { hari }\end{array}$ & $\begin{array}{c}\mathrm{mg} / \mathrm{kg}- \\
\text { hari }\end{array}$ & \\
\hline $\begin{array}{c}\text { Dewasa }(\mathrm{BT} \\
=70 \mathrm{Kg})\end{array}$ & 2.05 & 2 & 365 & 30 & $\begin{array}{l}7 \\
0\end{array}$ & $\begin{array}{c}109 \\
50\end{array}$ & 0.059 & 0.005 & 11.714 & $\begin{array}{c}\text { Beres } \\
\text { iko }\end{array}$ \\
\hline $\begin{array}{c}\text { Dewasa }(\mathrm{BT} \\
=55 \mathrm{Kg})\end{array}$ & 2.05 & 2 & 365 & 30 & 5 & $\begin{array}{c}109 \\
50\end{array}$ & 0.075 & 0.005 & 14.909 & $\begin{array}{c}\text { Beres } \\
\text { iko }\end{array}$ \\
\hline Aanak -anak & 2.05 & 1 & 365 & 6 & $\begin{array}{l}1 \\
5\end{array}$ & $\begin{array}{c}219 \\
0\end{array}$ & 0.137 & 0.005 & 27.333 & $\begin{array}{c}\text { Beres } \\
\text { iko }\end{array}$ \\
\hline
\end{tabular}

Sumber : Hasil Analisa

Tabel 9. Perhitungan analisa Resiko Dengan Parameter $\mathrm{Ca}_{2}{ }^{+}$(Kalsium)

\begin{tabular}{|c|c|c|c|c|c|c|c|c|c|c|}
\hline \multirow{2}{*}{ Konsumsi } & C & IR & FP & $\begin{array}{l}\mathrm{W} \\
\mathrm{P}\end{array}$ & $\begin{array}{l}\mathrm{B} \\
\mathrm{T}\end{array}$ & WR & I & RfD & HI & \multirow{2}{*}{$\begin{array}{c}\text { Resik } \\
0\end{array}$} \\
\hline & $\begin{array}{c}\mathrm{mg} / \mathrm{l} \\
\text { iter } \\
\end{array}$ & $\begin{array}{l}\text { liter/ } \\
\text { hari }\end{array}$ & $\begin{array}{c}\text { hari/ta } \\
\text { hun }\end{array}$ & $\begin{array}{l}\text { tah } \\
\text { un }\end{array}$ & $\begin{array}{l}\mathrm{K} \\
\mathrm{g} \\
\end{array}$ & $\begin{array}{c}\text { Har } \\
\mathrm{i}\end{array}$ & $\begin{array}{l}\mathrm{mg} / \mathrm{kg}- \\
\text { hari }\end{array}$ & $\begin{array}{l}\mathrm{mg} / \mathrm{kg}- \\
\text { hari }\end{array}$ & $\begin{array}{c}\mathrm{mg} / \mathrm{kg}- \\
\text { hari }\end{array}$ & \\
\hline $\begin{array}{c}\text { Dewasa (BT } \\
=70 \mathrm{Kg})\end{array}$ & $\begin{array}{c}41.5 \\
8\end{array}$ & 2 & 365 & 30 & $\begin{array}{l}7 \\
0\end{array}$ & $\begin{array}{c}109 \\
50\end{array}$ & 1.188 & 0.0006 & $\begin{array}{c}1980.0 \\
00\end{array}$ & $\begin{array}{c}\text { Beres } \\
\text { iko }\end{array}$ \\
\hline $\begin{array}{c}\text { Dewasa (BT } \\
=55 \mathrm{Kg} \text { ) }\end{array}$ & $\begin{array}{c}41.5 \\
8\end{array}$ & 2 & 365 & 30 & $\begin{array}{l}5 \\
5\end{array}$ & $\begin{array}{c}109 \\
50\end{array}$ & 1.512 & 0.0006 & $\begin{array}{c}2520.0 \\
00\end{array}$ & $\begin{array}{c}\text { Beres } \\
\text { iko }\end{array}$ \\
\hline Aanak -anak & $\begin{array}{c}41.5 \\
8\end{array}$ & 1 & 365 & 6 & $\begin{array}{l}1 \\
5\end{array}$ & $\begin{array}{c}219 \\
0\end{array}$ & 2.772 & 0.0006 & $\begin{array}{c}4620.0 \\
00\end{array}$ & $\begin{array}{c}\text { Beres } \\
\text { iko }\end{array}$ \\
\hline
\end{tabular}

Sumber : Hasil Analisa

Jadi pada analisa evaluasi terhadap kontaminan pada parameter yang telah ditentukan dapat disimpulkan bahwa pada sumur 1 untuk semua parameter terpilih mempunyai faktor resiko terhadap kesehatan, kecuali pada parameter $\mathrm{Fe}$ (Besi), yang jika dilihat pada tabel 6 kandungan HI (Hitung Indeks) dalam rumus $\mathrm{HI}=\mathrm{I} / \mathrm{RfD}$, yaitu kurang dari 1 dalam arti pada parameter ini tidak beresiko

\section{Sumur 2}

Tabel 10. Perhitungan analisa Resiko Dengan Parameter $\mathrm{Cl}^{-}$(Klorida)

\begin{tabular}{|c|c|c|c|c|c|c|c|c|c|c|}
\hline \multirow{2}{*}{ Konsumsi } & C & IR & FP & $\begin{array}{l}\mathrm{W} \\
\mathrm{P}\end{array}$ & $\begin{array}{l}\mathrm{B} \\
\mathrm{T}\end{array}$ & WR & I & RfD & $\mathrm{HI}$ & \multirow{2}{*}{$\begin{array}{c}\text { Resik } \\
0\end{array}$} \\
\hline & $\begin{array}{l}\mathrm{mg} / \mathrm{l} \\
\text { iter }\end{array}$ & $\begin{array}{l}\text { liter/ } \\
\text { hari }\end{array}$ & $\begin{array}{c}\text { hari/ta } \\
\text { hun }\end{array}$ & $\begin{array}{l}\text { tah } \\
\text { un }\end{array}$ & $\begin{array}{l}\mathrm{K} \\
\mathrm{g}\end{array}$ & $\begin{array}{c}\text { Har } \\
\mathrm{i}\end{array}$ & $\begin{array}{c}\mathrm{mg} / \mathrm{kg}- \\
\text { hari }\end{array}$ & $\begin{array}{c}\mathrm{mg} / \mathrm{kg}- \\
\text { hari }\end{array}$ & $\begin{array}{c}\mathrm{mg} / \mathrm{kg}- \\
\text { hari }\end{array}$ & \\
\hline $\begin{array}{c}\text { Dewasa (BT } \\
=70 \mathrm{Kg} \text { ) }\end{array}$ & $\begin{array}{c}34.2 \\
02\end{array}$ & 2 & 365 & 30 & $\begin{array}{l}7 \\
0\end{array}$ & $\begin{array}{c}109 \\
50\end{array}$ & 0.977 & 0.204 & 4.790 & $\begin{array}{c}\text { Beres } \\
\text { iko }\end{array}$ \\
\hline $\begin{array}{c}\text { Dewasa (BT } \\
=55 \mathrm{Kg} \text { ) }\end{array}$ & $\begin{array}{c}34.2 \\
02\end{array}$ & 2 & 365 & 30 & $\begin{array}{l}5 \\
5\end{array}$ & $\begin{array}{c}109 \\
50\end{array}$ & 1.244 & 0.204 & 6.097 & $\begin{array}{c}\text { Beres } \\
\text { iko }\end{array}$ \\
\hline Aanak -anak & $\begin{array}{c}34.2 \\
02\end{array}$ & 1 & 365 & 6 & $\begin{array}{l}1 \\
5\end{array}$ & $\begin{array}{c}219 \\
0\end{array}$ & 2.280 & 0.204 & 11.177 & $\begin{array}{c}\text { Beres } \\
\text { iko }\end{array}$ \\
\hline
\end{tabular}

Sumber : Hasil Analisa 
Tabel 11. Perhitungan analisa Resiko Dengan Parameter $\mathrm{SO}_{4}^{-}$(Sulfat)

\begin{tabular}{|c|c|c|c|c|c|c|c|c|c|c|}
\hline \multirow{2}{*}{ Konsumsi } & C & IR & FP & WP & $\begin{array}{l}\mathrm{B} \\
\mathrm{T}\end{array}$ & WR & I & RfD & HI & \multirow{2}{*}{$\begin{array}{c}\text { Resik } \\
0\end{array}$} \\
\hline & $\begin{array}{l}\mathrm{mg} / \\
\text { liter }\end{array}$ & $\begin{array}{l}\text { liter/ } \\
\text { hari }\end{array}$ & $\begin{array}{c}\text { hari/ta } \\
\text { hun }\end{array}$ & $\begin{array}{l}\text { tah } \\
\text { un }\end{array}$ & $\begin{array}{l}\mathrm{K} \\
\mathrm{g}\end{array}$ & Hari & $\begin{array}{c}\mathrm{mg} / \mathrm{kg}- \\
\text { hari }\end{array}$ & $\begin{array}{l}\mathrm{mg} / \mathrm{kg}- \\
\text { hari }\end{array}$ & $\begin{array}{c}\mathrm{mg} / \mathrm{kg}- \\
\text { hari }\end{array}$ & \\
\hline $\begin{array}{c}\text { Dewasa } \\
(\mathrm{BT}= \\
70 \mathrm{Kg})\end{array}$ & $\begin{array}{c}20.9 \\
3\end{array}$ & 2 & 365 & 30 & 70 & $\begin{array}{c}109 \\
50\end{array}$ & 0.598 & 0.408 & 1.466 & $\begin{array}{c}\text { Beres } \\
\text { iko }\end{array}$ \\
\hline $\begin{array}{c}\text { Dewasa } \\
(\mathrm{BT}= \\
55 \mathrm{Kg})\end{array}$ & 20.93 & 2 & 365 & 30 & 55 & $\begin{array}{c}109 \\
50\end{array}$ & .761 & 408 & 1.865 & $\begin{array}{l}\text { Ber } \\
\text { esi }\end{array}$ \\
\hline $\begin{array}{c}\text { Aanak - } \\
\text { anak }\end{array}$ & .93 & 2 & 365 & 6 & 15 & $\begin{array}{c}219 \\
0\end{array}$ & 2.791 & 408 & 6.840 & \\
\hline
\end{tabular}

Sumber : Hasil Analisa

Tabel 12. Perhitungan analisa Resiko Dengan Parameter $\mathrm{Mg}^{2+}$ (Mangan)

\begin{tabular}{|c|c|c|c|c|c|c|c|c|c|c|}
\hline \multirow{2}{*}{ Konsumsi } & $\mathrm{C}$ & IR & FP & $\begin{array}{l}\mathrm{W} \\
\mathrm{P}\end{array}$ & $\begin{array}{l}\mathrm{B} \\
\mathrm{T}\end{array}$ & WR & I & RfD & HI & \multirow{2}{*}{$\begin{array}{c}\text { Resik } \\
0\end{array}$} \\
\hline & $\begin{array}{c}\mathrm{mg} / \mathrm{l} \\
\text { iter }\end{array}$ & $\begin{array}{l}\text { liter/ } \\
\text { hari }\end{array}$ & $\begin{array}{c}\text { hari/ta } \\
\text { hun }\end{array}$ & $\begin{array}{l}\text { tah } \\
\text { un }\end{array}$ & $\begin{array}{l}\mathrm{K} \\
\mathrm{g}\end{array}$ & $\begin{array}{c}\mathrm{Har} \\
\mathrm{i}\end{array}$ & $\begin{array}{c}\mathrm{mg} / \mathrm{kg}- \\
\text { hari }\end{array}$ & $\begin{array}{c}\mathrm{mg} / \mathrm{kg}- \\
\text { hari }\end{array}$ & $\begin{array}{c}\mathrm{mg} / \mathrm{kg}- \\
\text { hari }\end{array}$ & \\
\hline $\begin{array}{c}\text { Dewasa (BT } \\
=70 \mathrm{Kg})\end{array}$ & $\begin{array}{c}24,3 \\
2\end{array}$ & 2 & 365 & 30 & $\begin{array}{l}7 \\
0\end{array}$ & $\begin{array}{c}109 \\
50\end{array}$ & 0,695 & 0,005 & $\begin{array}{c}138,97 \\
1\end{array}$ & $\begin{array}{c}\text { Beres } \\
\text { iko }\end{array}$ \\
\hline $\begin{array}{c}\text { Dewasa }(\mathrm{BT} \\
=55 \mathrm{Kg})\end{array}$ & $\begin{array}{c}24,3 \\
2\end{array}$ & 2 & 365 & 30 & $\begin{array}{l}5 \\
5\end{array}$ & $\begin{array}{c}109 \\
50\end{array}$ & 0,884 & 0,005 & $\begin{array}{c}176,87 \\
3\end{array}$ & $\begin{array}{c}\text { Beres } \\
\text { iko }\end{array}$ \\
\hline Aanak -anak & $\begin{array}{c}24,3 \\
2\end{array}$ & 1 & 365 & 6 & $\begin{array}{l}1 \\
5\end{array}$ & $\begin{array}{c}219 \\
0\end{array}$ & 1,621 & 0,005 & $\begin{array}{c}324,26 \\
7\end{array}$ & $\begin{array}{c}\text { Beres } \\
\text { iko }\end{array}$ \\
\hline
\end{tabular}

Sumber : Hasil Analisa

Tabel 13. Perhitungan analisa Resiko Dengan Parameter Fe (Besi)

\begin{tabular}{|c|c|c|c|c|c|c|c|c|c|c|}
\hline \multirow{2}{*}{ Konsumsi } & $\mathrm{C}$ & IR & FP & $\begin{array}{l}\mathrm{W} \\
\mathrm{P}\end{array}$ & $\begin{array}{l}\mathrm{B} \\
\mathrm{T}\end{array}$ & $\begin{array}{l}\mathrm{W} \\
\mathrm{R}\end{array}$ & I & RfD & $\mathrm{HI}$ & \multirow{2}{*}{ Resiko } \\
\hline & $\begin{array}{l}\mathrm{mg} / \mathrm{l} \\
\text { iter }\end{array}$ & $\begin{array}{l}\text { liter/ } \\
\text { hari }\end{array}$ & $\begin{array}{l}\text { hari/t } \\
\text { ahun }\end{array}$ & $\begin{array}{l}\text { tah } \\
\text { un }\end{array}$ & $\begin{array}{l}\mathrm{K} \\
\mathrm{g}\end{array}$ & $\begin{array}{c}\mathrm{Har} \\
\mathrm{i}\end{array}$ & $\begin{array}{c}\mathrm{mg} / \mathrm{kg} \\
\text {-hari }\end{array}$ & $\begin{array}{c}\mathrm{mg} / \mathrm{kg} \\
\text {-hari }\end{array}$ & $\begin{array}{c}\mathrm{mg} / \mathrm{kg} \\
\text {-hari }\end{array}$ & \\
\hline $\begin{array}{c}\text { Dewasa (BT } \\
=70 \mathrm{Kg})\end{array}$ & $\begin{array}{c}1,02 \\
2\end{array}$ & 2 & 365 & 30 & $\begin{array}{l}7 \\
0\end{array}$ & $\begin{array}{c}109 \\
50\end{array}$ & 0,029 & 0,7 & 0,042 & $\begin{array}{c}\text { Tidak } \\
\text { Beresiko }\end{array}$ \\
\hline $\begin{array}{c}\text { Dewasa }(\mathrm{BT} \\
=55 \mathrm{Kg})\end{array}$ & $\begin{array}{c}1,02 \\
2\end{array}$ & 2 & 365 & 30 & $\begin{array}{l}5 \\
5\end{array}$ & $\begin{array}{c}109 \\
50\end{array}$ & 0,037 & 0,7 & 0,053 & $\begin{array}{c}\text { Tidak } \\
\text { Beresiko }\end{array}$ \\
\hline Aanak -anak & $\begin{array}{c}1,02 \\
2 \\
\end{array}$ & 1 & 365 & 6 & $\begin{array}{l}1 \\
5 \\
\end{array}$ & $\begin{array}{c}219 \\
0\end{array}$ & 0,068 & 0,7 & 0,097 & $\begin{array}{c}\text { Tidak } \\
\text { Beresiko } \\
\end{array}$ \\
\hline
\end{tabular}

Sumber : Hasil Analisa

Tabel 14. Perhitungan analisa Resiko Dengan Parameter $\mathrm{Na}^{+}$(Natrium)

\begin{tabular}{|c|c|c|c|c|c|c|c|c|c|c|}
\hline \multirow{2}{*}{ Konsum } & C & IR & FP & $\begin{array}{l}\text { W } \\
\text { P }\end{array}$ & $\begin{array}{l}\text { B } \\
T\end{array}$ & WR & I & RfD & $\mathrm{HI}$ & \multirow{2}{*}{$\begin{array}{c}\text { Resik } \\
0\end{array}$} \\
\hline & $\begin{array}{c}\mathrm{mg} / \mathrm{l} \\
\text { iter }\end{array}$ & $\begin{array}{l}\text { liter/ } \\
\text { hari }\end{array}$ & $\begin{array}{c}\text { hari/ta } \\
\text { hun }\end{array}$ & $\begin{array}{l}\text { tah } \\
\text { un }\end{array}$ & $\begin{array}{l}\mathrm{K} \\
\mathrm{g}\end{array}$ & $\begin{array}{c}\mathrm{Har} \\
\mathrm{i}\end{array}$ & $\begin{array}{c}\mathrm{mg} / \mathrm{kg}- \\
\text { hari }\end{array}$ & $\begin{array}{c}\mathrm{mg} / \mathrm{kg}- \\
\text { hari }\end{array}$ & $\begin{array}{c}\mathrm{mg} / \mathrm{kg}- \\
\text { hari }\end{array}$ & \\
\hline $\begin{array}{l}\text { Dewa } \\
=7\end{array}$ & $\begin{array}{c}29.8 \\
6\end{array}$ & 2 & 365 & 30 & $\begin{array}{l}7 \\
0\end{array}$ & $\begin{array}{c}109 \\
50\end{array}$ & 0 & 03 & 28.438 & $\begin{array}{c}\text { Beres } \\
\text { iko }\end{array}$ \\
\hline $\begin{array}{c}\text { Dewasa }(\mathrm{BT} \\
=55 \mathrm{Kg})\end{array}$ & $\begin{array}{c}29.8 \\
6\end{array}$ & 2 & 365 & 30 & $\begin{array}{l}5 \\
5\end{array}$ & $\begin{array}{c}109 \\
50\end{array}$ & 1.086 & 0.03 & 36.194 & $\begin{array}{c}\text { Beres } \\
\text { iko }\end{array}$ \\
\hline Aanak -anak & $\begin{array}{c}29.8 \\
6 \\
\end{array}$ & 1 & 365 & 6 & $\begin{array}{l}1 \\
5 \\
\end{array}$ & $\begin{array}{c}219 \\
0 \\
\end{array}$ & 1.991 & 0.03 & 66.356 & $\begin{array}{c}\text { Beres } \\
\text { iko }\end{array}$ \\
\hline
\end{tabular}

Sumber : Hasil Analisa

Tabel 15. Perhitungan analisa Resiko Dengan Parameter $\mathrm{K}^{+}$(Kalium)

\begin{tabular}{|c|c|c|c|c|c|c|c|c|c|c|}
\hline Konsumsi & $\mathrm{C}$ & IR & FP & $\begin{array}{l}\mathrm{W} \\
\mathrm{P}\end{array}$ & $\begin{array}{l}\mathrm{B} \\
\mathrm{T}\end{array}$ & WR & I & RfD & HI & $\begin{array}{c}\text { Resik } \\
0\end{array}$ \\
\hline & $\begin{array}{l}\mathrm{mg} / \mathrm{l} \\
\text { iter }\end{array}$ & $\begin{array}{l}\text { liter/ } \\
\text { hari }\end{array}$ & $\begin{array}{c}\text { hari/ta } \\
\text { hun }\end{array}$ & $\begin{array}{l}\text { tah } \\
\text { un }\end{array}$ & $\begin{array}{l}\mathrm{K} \\
\mathrm{g}\end{array}$ & $\begin{array}{c}\text { Har } \\
\mathrm{i}\end{array}$ & $\begin{array}{c}\mathrm{mg} / \mathrm{kg}- \\
\text { hari }\end{array}$ & $\begin{array}{c}\mathrm{mg} / \mathrm{kg}- \\
\text { hari }\end{array}$ & $\begin{array}{c}\mathrm{mg} / \mathrm{kg}- \\
\text { hari }\end{array}$ & \\
\hline $\begin{array}{c}\text { Dewasa (BT } \\
=70 \mathrm{Kg} \text { ) }\end{array}$ & 8.24 & 2 & 365 & 30 & $\begin{array}{l}7 \\
0\end{array}$ & $\begin{array}{c}109 \\
50\end{array}$ & 0.235 & 0.005 & 47.086 & $\begin{array}{c}\text { Beres } \\
\text { iko }\end{array}$ \\
\hline $\begin{array}{c}\text { Dewasa (BT } \\
=55 \mathrm{Kg} \text { ) }\end{array}$ & 8.24 & 2 & 365 & 30 & $\begin{array}{l}5 \\
5\end{array}$ & $\begin{array}{c}109 \\
50\end{array}$ & 0.300 & 0.005 & 59.927 & $\begin{array}{c}\text { Beres } \\
\text { iko }\end{array}$ \\
\hline Aanak & 8.24 & 1 & 365 & 6 & $\begin{array}{l}1 \\
5\end{array}$ & $\begin{array}{c}219 \\
0\end{array}$ & 0.549 & 0.005 & $\begin{array}{c}109.86 \\
7\end{array}$ & $\begin{array}{c}\text { Beres } \\
\text { iko }\end{array}$ \\
\hline
\end{tabular}

Sumber : Hasil Analisa
Tabel 16. Perhitungan analisa Resiko Dengan Parameter $\mathrm{Ca}_{2}{ }^{+}$(Kalsium)

\begin{tabular}{|c|c|c|c|c|c|c|c|c|c|c|}
\hline \multirow{2}{*}{ Konsumsi } & $\mathrm{C}$ & IP & FP & $\begin{array}{l}\text { W } \\
P\end{array}$ & $\begin{array}{l}\mathrm{B} \\
\mathrm{T}\end{array}$ & WP & I & fD & HI & \multirow{2}{*}{$\begin{array}{c}\text { Resik } \\
0\end{array}$} \\
\hline & $\begin{array}{l}\mathrm{mg} / \mathrm{l} \\
\text { iter }\end{array}$ & $\begin{array}{l}\text { liter/ } \\
\text { hari }\end{array}$ & $\begin{array}{c}\text { hari/ta } \\
\text { hun }\end{array}$ & $\begin{array}{l}\text { tah } \\
\text { un }\end{array}$ & $\begin{array}{l}\mathrm{K} \\
\mathrm{g}\end{array}$ & $\begin{array}{c}\mathrm{Har} \\
\mathrm{i}\end{array}$ & $\begin{array}{c}\mathrm{mg} / \mathrm{kg}- \\
\text { hari }\end{array}$ & $\begin{array}{c}\mathrm{mg} / \mathrm{kg}- \\
\text { hari }\end{array}$ & $\begin{array}{c}\mathrm{mg} / \mathrm{kg}- \\
\text { hari }\end{array}$ & \\
\hline$=7$ & $\begin{array}{c}48.9 \\
3\end{array}$ & 2 & 365 & 30 & $\begin{array}{l}7 \\
0\end{array}$ & $\begin{array}{l}109 \\
50\end{array}$ & 398 & 06 & $\begin{array}{c}2330.0 \\
00\end{array}$ & $\begin{array}{c}\text { Beres } \\
\text { iko }\end{array}$ \\
\hline $\begin{array}{r}\text { Dewa } \\
=5 .\end{array}$ & $\begin{array}{c}48.9 \\
3\end{array}$ & 2 & 65 & 30 & 5 & $\begin{array}{l}109 \\
50\end{array}$ & 1.779 & 0.0006 & $\begin{array}{c}2965.4 \\
55\end{array}$ & $\begin{array}{c}\text { Beres } \\
\text { iko }\end{array}$ \\
\hline Aanak - & $\begin{array}{c}48.9 \\
3\end{array}$ & 1 & 365 & 6 & $\begin{array}{l}1 \\
5\end{array}$ & $\begin{array}{c}219 \\
0\end{array}$ & 3.262 & 0.0006 & $\begin{array}{c}5436.6 \\
67\end{array}$ & $\begin{array}{c}\text { Beres } \\
\text { iko }\end{array}$ \\
\hline
\end{tabular}

Sumber: Hasil Analisa

Analisa evaluasi terhadap kontaminan pada parameter yang telah ditentukan dapat disimpulkan bahwa pada sumur 2 untuk semua parameter terpilih mempunyai faktor resiko terhadap kesehatan, kecuali pada parameter $\mathrm{Fe}$ (Besi), yang jika dilihat pada tabel 13 kandungan HI (Hitung Indeks) dalam rumus $\mathrm{HI}=\mathrm{I} / \mathrm{RfD}$, yaitu kurang dari 1 dalam arti pada parameter ini tidak beresiko.

Sumur 3

Tabel 17. Perhitungan analisa Resiko Dengan Parameter $\mathrm{Cl}^{-}$(Klorida)

\begin{tabular}{|c|c|c|c|c|c|c|c|c|c|c|}
\hline \multirow[b]{2}{*}{ K } & $\mathrm{C}$ & IR & FP & $\begin{array}{l}\text { W } \\
P\end{array}$ & $\begin{array}{l}\mathrm{B} \\
\mathrm{T}\end{array}$ & WR & I & $\mathrm{fD}$ & HI & \multirow{2}{*}{$\begin{array}{c}\text { Resik } \\
0\end{array}$} \\
\hline & $\begin{array}{l}\mathrm{mg} / \mathrm{l} \\
\text { iter }\end{array}$ & $\begin{array}{l}\text { liter/ } \\
\text { hari }\end{array}$ & $\begin{array}{l}\text { hari/ta } \\
\text { hun }\end{array}$ & $\begin{array}{l}\text { tah } \\
\text { un }\end{array}$ & $\begin{array}{l}\mathrm{K} \\
\mathrm{g}\end{array}$ & $\begin{array}{c}\text { Har } \\
\text { i }\end{array}$ & $\begin{array}{c}\mathrm{mg} / \mathrm{kg}- \\
\text { hari }\end{array}$ & $\begin{array}{c}\mathrm{mg} / \mathrm{kg}- \\
\text { hari }\end{array}$ & $\begin{array}{c}\mathrm{mg} / \mathrm{kg}- \\
\text { hari }\end{array}$ & \\
\hline $\begin{array}{r}\text { Dew: } \\
=7\end{array}$ & $\begin{array}{c}55.1 \\
03\end{array}$ & 2 & 365 & 30 & $\begin{array}{l}7 \\
0\end{array}$ & $\begin{array}{l}109 \\
50\end{array}$ & 1.574 & 0.204 & 7.718 & iko \\
\hline $\begin{array}{r}\text { Dewasa } \\
=55 \mathrm{~K}\end{array}$ & $\begin{array}{c}55.1 \\
03\end{array}$ & 2 & 365 & 30 & $\begin{array}{l}5 \\
5\end{array}$ & $\begin{array}{l}109 \\
50\end{array}$ & 2.004 & 0.204 & 9.822 & $\begin{array}{c}\text { Beres } \\
\text { iko }\end{array}$ \\
\hline nak - & $\begin{array}{c}55.1 \\
03\end{array}$ & 1 & 365 & 6 & $\begin{array}{l}1 \\
5 \\
\end{array}$ & $\begin{array}{c}219 \\
0 \\
\end{array}$ & 3.674 & 0.204 & 18.008 & $\begin{array}{c}\text { Beres } \\
\text { iko }\end{array}$ \\
\hline
\end{tabular}

Sumber : Hasil Analisa

Tabel 18. Perhitungan analisa Resiko Dengan Parameter $\mathrm{SO}_{4}^{-}$(Sulfat)

\begin{tabular}{|c|c|c|c|c|c|c|c|c|c|c|}
\hline \multirow{2}{*}{ Konsumsi } & C & IR & FP & $\begin{array}{l}\mathrm{W} \\
\mathrm{P}\end{array}$ & $\begin{array}{l}\mathrm{B} \\
\mathrm{T}\end{array}$ & WR & I & RfD & HI & \multirow{2}{*}{$\begin{array}{c}\text { Resik } \\
0\end{array}$} \\
\hline & $\begin{array}{l}\mathrm{mg} / \mathrm{l} \\
\text { iter }\end{array}$ & $\begin{array}{l}\text { liter/ } \\
\text { hari }\end{array}$ & $\begin{array}{l}\text { hari/ta } \\
\text { hun }\end{array}$ & $\begin{array}{l}\text { tah } \\
\text { un }\end{array}$ & $\begin{array}{l}\mathrm{K} \\
\mathrm{g}\end{array}$ & $\begin{array}{c}\mathrm{Har} \\
\mathrm{i}\end{array}$ & $\begin{array}{c}\mathrm{mg} / \mathrm{kg}- \\
\text { hari }\end{array}$ & $\begin{array}{c}\mathrm{mg} / \mathrm{kg}- \\
\text { hari }\end{array}$ & $\begin{array}{c}\mathrm{mg} / \mathrm{kg}- \\
\text { hari }\end{array}$ & \\
\hline $\begin{array}{c}\text { Dewasa (BT } \\
=70 \mathrm{Kg})\end{array}$ & $\begin{array}{c}14.5 \\
35\end{array}$ & 2 & 365 & 30 & $\begin{array}{l}7 \\
0\end{array}$ & $\begin{array}{c}109 \\
50\end{array}$ & 0.415 & 0.408 & 1.018 & $\begin{array}{c}\text { Beres } \\
\text { iko }\end{array}$ \\
\hline $\begin{array}{c}\text { Dewasa (BT } \\
=55 \mathrm{Kg})\end{array}$ & $\begin{array}{c}14.5 \\
35\end{array}$ & 2 & 365 & 30 & $\begin{array}{l}5 \\
5\end{array}$ & $\begin{array}{c}109 \\
50\end{array}$ & 0.529 & 0.408 & 1.295 & $\begin{array}{c}\text { Beres } \\
\text { iko }\end{array}$ \\
\hline Aanak -anak & $\begin{array}{c}14.5 \\
35\end{array}$ & 1 & 365 & 6 & $\begin{array}{l}1 \\
5\end{array}$ & $\begin{array}{c}219 \\
0\end{array}$ & 0.969 & 0.408 & 2.375 & $\begin{array}{c}\text { Beres } \\
\text { iko }\end{array}$ \\
\hline
\end{tabular}

Sumber : Hasil Analisa

Tabel 19. Perhitungan analisa Resiko Dengan Parameter $\mathrm{Mg}^{2+}$ (Mangan)

\begin{tabular}{|c|c|c|c|c|c|c|c|c|c|c|}
\hline \multirow{2}{*}{ Konsumsi } & C & IR & FP & $\begin{array}{l}\mathrm{W} \\
\mathrm{P}\end{array}$ & $\begin{array}{l}B \\
T\end{array}$ & WR & I & RfD & HI & \multirow{2}{*}{$\begin{array}{c}\text { Resik } \\
0\end{array}$} \\
\hline & $\begin{array}{l}\mathrm{mg} / \mathrm{l} \\
\text { iter }\end{array}$ & $\begin{array}{l}\text { liter/ } \\
\text { hari }\end{array}$ & $\begin{array}{c}\text { hari/ta } \\
\text { hun }\end{array}$ & $\begin{array}{l}\text { tah } \\
\text { un }\end{array}$ & $\begin{array}{l}K \\
g\end{array}$ & $\begin{array}{c}\mathrm{Har} \\
\mathrm{i}\end{array}$ & $\begin{array}{l}\mathrm{mg} / \mathrm{kg}- \\
\text { hari }\end{array}$ & $\begin{array}{l}\mathrm{mg} / \mathrm{kg}- \\
\text { hari }\end{array}$ & $\begin{array}{l}\mathrm{mg} / \mathrm{kg}- \\
\text { hari }\end{array}$ & \\
\hline $\begin{array}{c}\text { Dewasa (BT } \\
=70 \mathrm{Kg} \text { ) }\end{array}$ & $\begin{array}{c}16.5 \\
3\end{array}$ & 2 & 365 & 30 & 7 & $\begin{array}{c}109 \\
50\end{array}$ & 0.472 & 0.005 & 94.457 & $\begin{array}{c}\text { Beres } \\
\text { iko }\end{array}$ \\
\hline $\begin{array}{c}\text { Dewasa (BT } \\
=55 \mathrm{Kg} \text { ) }\end{array}$ & $\begin{array}{c}16.5 \\
3\end{array}$ & 2 & 365 & 30 & $\begin{array}{l}5 \\
5\end{array}$ & $\begin{array}{c}109 \\
50\end{array}$ & 0.601 & 0.005 & $\begin{array}{c}120.21 \\
8\end{array}$ & $\begin{array}{c}\text { Beres } \\
\text { iko }\end{array}$ \\
\hline Aanak -anak & $\begin{array}{c}16.5 \\
3\end{array}$ & 1 & 365 & 6 & 5 & $\begin{array}{c}219 \\
0\end{array}$ & 1.102 & 0.005 & $\begin{array}{c}220.40 \\
0\end{array}$ & $\begin{array}{c}\text { Beres } \\
\text { iko }\end{array}$ \\
\hline
\end{tabular}

Sumber : Hasil Analisa 
Tabel 20. Perhitungan analisa Resiko Dengan Parameter Fe (Besi)

\begin{tabular}{|c|c|c|c|c|c|c|c|c|c|c|}
\hline \multirow{2}{*}{ Konsumsi } & C & IR & FP & $\begin{array}{l}\text { W } \\
P\end{array}$ & $\begin{array}{l}\mathrm{B} \\
\mathrm{T}\end{array}$ & $\begin{array}{l}\mathrm{W} \\
\mathrm{R}\end{array}$ & I & RfD & $\mathrm{HI}$ & \multirow{2}{*}{ Resiko } \\
\hline & $\begin{array}{l}\mathrm{mg} / \mathrm{l} \\
\text { iter }\end{array}$ & $\begin{array}{l}\text { liter/ } \\
\text { hari }\end{array}$ & $\begin{array}{l}\text { hari/t } \\
\text { ahun }\end{array}$ & $\begin{array}{l}\text { tah } \\
\text { un }\end{array}$ & $\begin{array}{l}\mathrm{K} \\
\mathrm{g}\end{array}$ & $\begin{array}{c}\mathrm{Har} \\
\mathrm{i}\end{array}$ & $\begin{array}{l}\mathrm{mg} / \mathrm{kg} \\
\text {-hari }\end{array}$ & $\begin{array}{l}\mathrm{mg} / \mathrm{kg} \\
\text {-hari }\end{array}$ & $\begin{array}{l}\mathrm{mg} / \mathrm{kg} \\
\text {-hari }\end{array}$ & \\
\hline $\begin{array}{c}\text { Dewasa (BT } \\
=70 \mathrm{Kg})\end{array}$ & 0,31 & 2 & 365 & 30 & $\begin{array}{l}7 \\
0\end{array}$ & $\begin{array}{c}109 \\
50\end{array}$ & 0,009 & 0, & 0,013 & $\begin{array}{c}\text { Tidak } \\
\text { Beresiko }\end{array}$ \\
\hline $\begin{array}{c}\text { Dewasa (BT } \\
=55 \mathrm{Kg})\end{array}$ & 0,31 & 2 & 365 & 30 & $\begin{array}{l}5 \\
5\end{array}$ & $\begin{array}{c}109 \\
50\end{array}$ & 011 & 0,7 & 0,016 & $\begin{array}{c}\text { Tidak } \\
\text { Beresiko }\end{array}$ \\
\hline Aanak -anak & 0,31 & 1 & 365 & 6 & $\begin{array}{l}1 \\
5\end{array}$ & $\begin{array}{c}219 \\
0\end{array}$ & 0,021 & 0,7 & 0,030 & $\begin{array}{c}\text { Tidak } \\
\text { Beresiko }\end{array}$ \\
\hline
\end{tabular}

Sumber : Hasil Analisa

Tabel 21. Perhitungan analisa Resiko Dengan Parameter $\mathrm{Na}^{+}$(Natrium)

\begin{tabular}{|c|c|c|c|c|c|c|c|c|c|c|}
\hline \multirow[b]{2}{*}{ Konsumsi } & $\mathrm{C}$ & IR & FP & W & B & WR & I & RfD & $\mathrm{HI}$ & \multirow{2}{*}{$\begin{array}{c}\text { Resik } \\
0\end{array}$} \\
\hline & $\begin{array}{c}\mathrm{mg} / \mathrm{l} \\
\text { iter }\end{array}$ & $\begin{array}{l}\text { liter/ } \\
\text { hari }\end{array}$ & $\begin{array}{c}\text { hari/ta } \\
\text { hun }\end{array}$ & $\begin{array}{l}\text { tah } \\
\text { un }\end{array}$ & $\begin{array}{l}\mathrm{I} \\
\mathrm{K} \\
\mathrm{g}\end{array}$ & $\begin{array}{c}\mathrm{Har} \\
\mathrm{i}\end{array}$ & $\begin{array}{c}\mathrm{mg} / \mathrm{kg}- \\
\text { hari }\end{array}$ & $\begin{array}{c}\mathrm{mg} / \mathrm{kg}- \\
\text { hari }\end{array}$ & $\begin{array}{c}\mathrm{mg} / \mathrm{kg}- \\
\text { hari }\end{array}$ & \\
\hline $\begin{array}{c}\text { Dewasa }(\mathrm{BT} \\
=70 \mathrm{Kg})\end{array}$ & $\begin{array}{c}35.0 \\
0\end{array}$ & 2 & 365 & 30 & $\begin{array}{l}7 \\
7 \\
0\end{array}$ & $\begin{array}{c}109 \\
50\end{array}$ & 1.000 & 0.03 & 33.333 & $\begin{array}{c}\text { Beres } \\
\text { iko }\end{array}$ \\
\hline $\begin{array}{c}\text { Dewasa }(\mathrm{BT} \\
=55 \mathrm{Kg})\end{array}$ & $\begin{array}{c}35.0 \\
0\end{array}$ & 2 & 365 & 30 & $\begin{array}{l}5 \\
5\end{array}$ & $\begin{array}{c}109 \\
50\end{array}$ & 1.273 & 0.03 & 42.424 & $\begin{array}{c}\text { Beres } \\
\text { iko }\end{array}$ \\
\hline Aanak -anak & $\begin{array}{c}35.0 \\
0\end{array}$ & 1 & 365 & 6 & $\begin{array}{l}1 \\
5\end{array}$ & $\begin{array}{c}219 \\
0\end{array}$ & 2.333 & 0.03 & 77.778 & $\begin{array}{c}\text { Beres } \\
\text { iko }\end{array}$ \\
\hline
\end{tabular}

Sumber: Hasil Analisa

Tabel 22. Perhitungan analisa Resiko Dengan Parameter $\mathrm{K}^{+}$(Kalium)

\begin{tabular}{|c|c|c|c|c|c|c|c|c|c|c|}
\hline & C & IR & FP & $\begin{array}{l}\text { W } \\
\mathrm{P}\end{array}$ & & WR & I & $\mathrm{fD}$ & HI & Resik \\
\hline Ko & $\begin{array}{l}\mathrm{mg} / \mathrm{l} \\
\text { iter }\end{array}$ & $\begin{array}{l}\text { liter/ } \\
\text { hari }\end{array}$ & $\begin{array}{l}\text { hari/ta } \\
\text { hun }\end{array}$ & $\begin{array}{l}\text { tah } \\
\text { un }\end{array}$ & K & $\begin{array}{l}\text { Har } \\
\text { i }\end{array}$ & $\begin{array}{l}\mathrm{mg} / \mathrm{kg}- \\
\text { hari }\end{array}$ & $\begin{array}{l}\mathrm{mg} / \mathrm{kg}- \\
\text { hari }\end{array}$ & $\begin{array}{l}\mathrm{mg} / \mathrm{kg}- \\
\text { hari }\end{array}$ & 0 \\
\hline $\begin{array}{l}\text { Dewa } \\
=70 \mathrm{~K}\end{array}$ & 1.04 & 2 & 36 & 30 & 0 & $\begin{array}{r}109 \\
50\end{array}$ & 0.030 & 0.005 & 5.943 & $\begin{array}{l}\text { Beres } \\
\text { iko }\end{array}$ \\
\hline $\begin{array}{l}\text { Dewa } \\
=55 \mathrm{~K}\end{array}$ & 1.04 & 2 & 365 & 30 & & $\begin{array}{r}109 \\
50 \\
219\end{array}$ & 0.038 & 0.005 & 7.564 & $\begin{array}{l}\text { Beres } \\
\text { iko }\end{array}$ \\
\hline Aanak -anak & 1.04 & 1 & 365 & 6 & 5 & 0 & 0.069 & 0.005 & 13.867 & iko \\
\hline
\end{tabular}

Sumber: Hasil Analisa

Tabel 23. Perhitungan analisa Resiko Dengan Parameter $\mathrm{Ca}_{2}^{+}$(Kalsium)

\begin{tabular}{|c|c|c|c|c|c|c|c|c|c|c|}
\hline \multirow[b]{3}{*}{ Konsumsi } & & & & W & B & & & & & \multirow{3}{*}{$\begin{array}{l}\text { Resik } \\
0\end{array}$} \\
\hline & $\mathrm{C}$ & $\mathrm{IR}$ & FP & $\mathrm{P}$ & $\mathrm{T}$ & WR & I & RfD & $\mathrm{HI}$ & \\
\hline & $\begin{array}{l}\mathrm{mg} / \mathrm{l} \\
\text { iter }\end{array}$ & $\begin{array}{l}\text { liter/ } \\
\text { hari }\end{array}$ & $\begin{array}{l}\text { hari/ta } \\
\text { hun }\end{array}$ & $\begin{array}{l}\text { tah } \\
\text { un }\end{array}$ & $\begin{array}{l}\mathrm{K} \\
\mathrm{g}\end{array}$ & $\begin{array}{l}\text { Har } \\
\mathrm{i}\end{array}$ & $\begin{array}{l}\mathrm{mg} / \mathrm{kg}- \\
\text { hari }\end{array}$ & $\begin{array}{l}\mathrm{mg} / \mathrm{kg}- \\
\text { hari }\end{array}$ & $\begin{array}{l}\mathrm{mg} / \mathrm{kg}- \\
\text { hari }\end{array}$ & \\
\hline Dewas & 27.4 & & & & 7 & 109 & & & 1305.2 & Beres \\
\hline$=70 \mathrm{~K}$ & 1 & 2 & 365 & 30 & 0 & 50 & 0.783 & 0.0006 & 38 & iko \\
\hline Dewasa $(\mathrm{H}$ & 27.4 & & & & 5 & 109 & & & 1661.2 & Beres \\
\hline$=55 \mathrm{Kg}$ & 1 & 2 & 365 & 30 & 5 & 50 & 0.997 & 0.0006 & 12 & iko \\
\hline & 27.4 & & & & 1 & 219 & & & 3045.5 & Beres \\
\hline Aanak -anak & 1 & 1 & 365 & 6 & 5 & 0 & 1.827 & 0.0006 & 56 & iko \\
\hline
\end{tabular}

Sumber : Hasil Analisa

Pada sumur 3, analisa evaluasi terhadap kontaminan pada parameter yang telah ditentukan dapat disimpulkan bahwa untuk semua parameter terpilih mempunyai faktor resiko terhadap kesehatan, kecuali pada parameter $\mathrm{Fe}$ (Besi), yang jika dilihat pada tabel 21 kandungan HI (Hitung Indeks) dalam rumus $\mathrm{HI}=\mathrm{I} / \mathrm{RfD}$, yaitu kurang dari 1 dalam arti pada parameter ini tidak beresiko
Sumur 4

Tabel 24. Perhitungan analisa Resiko Dengan Parameter $\mathrm{Cl}^{-}$(Klorida)

\begin{tabular}{|c|c|c|c|c|c|c|c|c|c|c|}
\hline \multirow{2}{*}{ Konsumsi } & C & IR & FP & $\begin{array}{l}\text { W } \\
P\end{array}$ & $\begin{array}{l}\mathrm{B} \\
\mathrm{T}\end{array}$ & WR & I & RfD & HI & \multirow{2}{*}{$-\begin{array}{c}\text { Resik } \\
0\end{array}$} \\
\hline & $\begin{array}{c}\mathrm{mg} / \mathrm{l} \\
\text { iter }\end{array}$ & $\begin{array}{l}\text { liter/ } \\
\text { hari }\end{array}$ & $\begin{array}{c}\text { hari/ta } \\
\text { hun }\end{array}$ & $\begin{array}{l}\text { tah } \\
\text { un }\end{array}$ & $\begin{array}{l}\mathrm{K} \\
\mathrm{g}\end{array}$ & $\begin{array}{c}\mathrm{Har} \\
\mathrm{i} \\
\end{array}$ & $\begin{array}{c}\mathrm{mg} / \mathrm{kg}- \\
\text { hari }\end{array}$ & $\begin{array}{c}\mathrm{mg} / \mathrm{kg}- \\
\text { hari }\end{array}$ & $\begin{array}{c}\mathrm{mg} / \mathrm{kg}- \\
\text { hari }\end{array}$ & \\
\hline $\begin{array}{c}\text { Dewasa (BT } \\
=70 \mathrm{Kg})\end{array}$ & $\begin{array}{c}39.9 \\
03\end{array}$ & 2 & 365 & 30 & $\begin{array}{l}7 \\
0\end{array}$ & $\begin{array}{c}109 \\
50\end{array}$ & 1.140 & 0.204 & 5.589 & $\begin{array}{c}\text { Beres } \\
\text { iko }\end{array}$ \\
\hline $\begin{array}{c}\text { Dewasa (BT } \\
=55 \mathrm{Kg})\end{array}$ & $\begin{array}{c}39.9 \\
03\end{array}$ & 2 & 365 & 30 & $\begin{array}{l}5 \\
5\end{array}$ & $\begin{array}{c}109 \\
50\end{array}$ & 1.451 & 0.204 & 7.113 & $\begin{array}{c}\text { Beres } \\
\text { iko }\end{array}$ \\
\hline Aanak -anak & $\begin{array}{c}39.9 \\
03\end{array}$ & 1 & 365 & 6 & $\begin{array}{l}1 \\
5\end{array}$ & $\begin{array}{c}219 \\
0\end{array}$ & 2.660 & 0.204 & 13.040 & $\begin{array}{c}\text { Beres } \\
\text { iko }\end{array}$ \\
\hline
\end{tabular}

Sumber : Hasil Analisa

Tabel 25. Perhitungan analisa Resiko Dengan Parameter $\mathrm{SO}_{4}^{-}$(Sulfat)

\begin{tabular}{ccccccccccc}
\hline Konsumsi & C & IR & FP & $\begin{array}{c}\text { W } \\
\text { P }\end{array}$ & $\begin{array}{c}\text { B } \\
\text { TR }\end{array}$ & I & RfD & HI & $\begin{array}{c}\text { Resik } \\
0\end{array}$ \\
\hline & $\begin{array}{c}\mathrm{mg} / \mathrm{l} \\
\text { iter }\end{array}$ & $\begin{array}{c}\text { liter/ } \\
\text { hari }\end{array}$ & $\begin{array}{c}\text { hari/ta } \\
\text { hun }\end{array}$ & $\begin{array}{c}\text { tah } \\
\text { un }\end{array}$ & $\begin{array}{c}\text { K } \\
\text { g }\end{array}$ & $\begin{array}{c}\text { Har } \\
\text { i }\end{array}$ & $\begin{array}{c}\mathrm{mg} / \mathrm{kg}- \\
\text { hari }\end{array}$ & $\begin{array}{c}\mathrm{mg} / \mathrm{kg}- \\
\text { hari }\end{array}$ & $\begin{array}{c}\mathrm{mg} / \mathrm{kg}- \\
\text { hari }\end{array}$ \\
\hline $\begin{array}{c}\text { Dewasa (BT } \\
=70 \mathrm{Kg})\end{array}$ & $\begin{array}{c}19,7 \\
67\end{array}$ & 2 & 365 & 30 & 7 & 109 & 0,565 & 0,408 & 1,384 & $\begin{array}{c}\text { Beres } \\
\text { iko }\end{array}$ \\
$\begin{array}{c}\text { Dewasa (BT } \\
\text { =55Kg) }\end{array}$ & $\begin{array}{c}19,7 \\
67\end{array}$ & 2 & 365 & 30 & 5 & 109 & 0,719 & 0,408 & 1,762 & $\begin{array}{c}\text { Beres } \\
\text { iko }\end{array}$ \\
Aanak -anak & $\begin{array}{c}19,7 \\
67\end{array}$ & 1 & 365 & 6 & 1 & 219 & 1,318 & 0,408 & 3,230 & $\begin{array}{c}\text { Beres } \\
\text { iko }\end{array}$ \\
\hline
\end{tabular}

Sumber : Hasil Analisa

Tabel 26. Perhitungan analisa Resiko Dengan Parameter $\mathrm{Mg}^{2+}$ (Mangan)

\begin{tabular}{|c|c|c|c|c|c|c|c|c|c|c|}
\hline \multirow{2}{*}{ Konsumsi } & C & IR & FP & $\begin{array}{l}\text { W } \\
\text { P }\end{array}$ & $\begin{array}{l}\mathrm{B} \\
\mathrm{T}\end{array}$ & WR & I & RfD & $\mathrm{HI}$ & \multirow{2}{*}{$-\begin{array}{c}\text { Resik } \\
0\end{array}$} \\
\hline & $\begin{array}{l}\mathrm{mg} / \mathrm{l} \\
\text { iter }\end{array}$ & $\begin{array}{l}\text { liter/ } \\
\text { hari }\end{array}$ & $\begin{array}{c}\text { hari/ta } \\
\text { hun }\end{array}$ & $\begin{array}{l}\text { tah } \\
\text { un }\end{array}$ & $\begin{array}{l}\mathrm{K} \\
\mathrm{g}\end{array}$ & $\begin{array}{c}\mathrm{Har} \\
\mathrm{i}\end{array}$ & $\begin{array}{c}\mathrm{mg} / \mathrm{kg}- \\
\text { hari }\end{array}$ & $\begin{array}{c}\mathrm{mg} / \mathrm{kg}- \\
\text { hari }\end{array}$ & $\begin{array}{c}\mathrm{mg} / \mathrm{kg}- \\
\text { hari }\end{array}$ & \\
\hline $\begin{array}{c}\text { Dewasa (BT } \\
=70 \mathrm{Kg})\end{array}$ & $\begin{array}{c}28,2 \\
3\end{array}$ & 2 & 365 & 30 & $\begin{array}{l}7 \\
0\end{array}$ & $\begin{array}{c}109 \\
50\end{array}$ & 07 & 005 & $\begin{array}{c}161,31 \\
4\end{array}$ & $\begin{array}{c}\text { Beres } \\
\text { iko }\end{array}$ \\
\hline $\begin{array}{c}\text { Dewasa }(\mathrm{BT} \\
=55 \mathrm{Kg})\end{array}$ & $\begin{array}{c}28,2 \\
3\end{array}$ & 2 & 365 & 30 & $\begin{array}{l}5 \\
5\end{array}$ & $\begin{array}{c}109 \\
50\end{array}$ & ,027 & 0,005 & $\begin{array}{c}205,30 \\
9\end{array}$ & $\begin{array}{c}\text { Beres } \\
\text { iko }\end{array}$ \\
\hline Aanak -anak & $\begin{array}{c}28,2 \\
3\end{array}$ & 1 & 365 & 6 & $\begin{array}{l}1 \\
5\end{array}$ & $\begin{array}{c}219 \\
0\end{array}$ & 1,882 & 0,005 & $\begin{array}{c}376,40 \\
0\end{array}$ & $\begin{array}{c}\text { Beres } \\
\text { iko }\end{array}$ \\
\hline
\end{tabular}

Sumber : Hasil Analisa

Tabel 27. Perhitungan analisa Resiko Dengan Parameter Fe (Besi)

\begin{tabular}{|c|c|c|c|c|c|c|c|c|c|c|}
\hline \multirow{2}{*}{ Konsumsi } & $\mathrm{C}$ & IR & FP & $\begin{array}{l}\mathrm{W} \\
\mathrm{P}\end{array}$ & $\begin{array}{l}\mathrm{B} \\
\mathrm{T}\end{array}$ & WR & I & RfD & HI & \multirow{2}{*}{$\begin{array}{c}\text { Resik } \\
0\end{array}$} \\
\hline & $\begin{array}{l}\mathrm{mg} / \mathrm{l} \\
\text { iter }\end{array}$ & $\begin{array}{l}\text { liter/ } \\
\text { hari }\end{array}$ & $\begin{array}{c}\text { hari/ta } \\
\text { hun }\end{array}$ & $\begin{array}{l}\text { tah } \\
\text { un }\end{array}$ & $\begin{array}{l}\mathrm{K} \\
\mathrm{g}\end{array}$ & $\begin{array}{c}\mathrm{Har} \\
\mathrm{i}\end{array}$ & $\begin{array}{c}\mathrm{mg} / \mathrm{kg}- \\
\text { hari }\end{array}$ & $\begin{array}{c}\mathrm{mg} / \mathrm{kg}- \\
\text { hari }\end{array}$ & $\begin{array}{c}\mathrm{mg} / \mathrm{kg}- \\
\text { hari }\end{array}$ & \\
\hline $\begin{array}{c}\text { Dewasa (BT } \\
=70 \mathrm{Kg})\end{array}$ & $\begin{array}{c}35.9 \\
3\end{array}$ & 2 & 365 & 30 & $\begin{array}{l}0 \\
0\end{array}$ & $\begin{array}{c}109 \\
50\end{array}$ & 1.027 & 0.03 & 34.219 & $\begin{array}{c}\text { Beres } \\
\text { iko }\end{array}$ \\
\hline $\begin{array}{c}\text { Dewasa }(\mathrm{BT} \\
=55 \mathrm{Kg})\end{array}$ & $\begin{array}{c}35.9 \\
3\end{array}$ & 2 & 365 & 30 & $\begin{array}{l}5 \\
5\end{array}$ & $\begin{array}{c}109 \\
50\end{array}$ & 1.307 & 0.03 & 3.552 & $\begin{array}{c}\text { Beres } \\
\text { iko }\end{array}$ \\
\hline Aanak -anak & $\begin{array}{c}35.9 \\
3\end{array}$ & 1 & 365 & 6 & $\begin{array}{l}1 \\
5\end{array}$ & $\begin{array}{c}219 \\
0\end{array}$ & 2.395 & 0.03 & 79.844 & $\begin{array}{c}\text { Beres } \\
\text { iko }\end{array}$ \\
\hline
\end{tabular}

Sumber : Hasil Analisa

Tabel 28. Perhitungan analisa Resiko Dengan Parameter $\mathrm{Na}^{+}$(Natrium)

\begin{tabular}{|c|c|c|c|c|c|c|c|c|c|c|}
\hline \multirow{2}{*}{ Konsum } & C & IR & FP & $\begin{array}{l}\mathrm{W} \\
\mathrm{P}\end{array}$ & $\begin{array}{l}\mathrm{B} \\
\mathrm{T}\end{array}$ & WR & I & RfD & $\mathrm{HI}$ & \multirow{2}{*}{$\begin{array}{c}\text { Resik } \\
0\end{array}$} \\
\hline & $\begin{array}{c}\mathrm{mg} / \mathrm{l} \\
\text { iter }\end{array}$ & $\begin{array}{c}\text { liter/ } \\
\text { hari }\end{array}$ & $\begin{array}{c}\text { hari/ta } \\
\text { hun }\end{array}$ & $\begin{array}{l}\text { tah } \\
\text { un } \\
\end{array}$ & $\begin{array}{l}\mathrm{K} \\
\mathrm{g}\end{array}$ & $\begin{array}{c}\text { Har } \\
\mathrm{i}\end{array}$ & $\begin{array}{c}\mathrm{mg} / \mathrm{kg}- \\
\text { hari }\end{array}$ & $\begin{array}{c}\mathrm{mg} / \mathrm{kg}- \\
\text { hari }\end{array}$ & $\begin{array}{c}\mathrm{mg} / \mathrm{kg}- \\
\text { hari }\end{array}$ & \\
\hline $\begin{array}{l}\text { Dew: } \\
=7\end{array}$ & $\begin{array}{c}35.9 \\
3\end{array}$ & 2 & 365 & 30 & $\begin{array}{l}7 \\
0\end{array}$ & $\begin{array}{c}109 \\
50\end{array}$ & 1.027 & 0.03 & 19 & $\begin{array}{c}\text { Beres } \\
\text { iko }\end{array}$ \\
\hline $\begin{array}{c}\text { Dewasa (BT } \\
=55 \mathrm{Kg})\end{array}$ & $\begin{array}{c}35.9 \\
3\end{array}$ & 2 & & 30 & $\begin{array}{l}5 \\
5\end{array}$ & $\begin{array}{c}109 \\
50\end{array}$ & & & 52 & $\begin{array}{c}\text { Beres } \\
\text { iko }\end{array}$ \\
\hline Aanak -anak & $\begin{array}{c}35.9 \\
3 \\
\end{array}$ & 1 & 30 & 6 & $\begin{array}{l}1 \\
5 \\
\end{array}$ & $\begin{array}{c}219 \\
0\end{array}$ & 2.395 & 0.03 & 79.844 & $\begin{array}{c}\text { Beres } \\
\text { iko }\end{array}$ \\
\hline
\end{tabular}

Sumber : Hasil Analisa 
Tabel 29. Perhitungan analisa Resiko Dengan Parameter $\mathrm{K}^{+}$(Kalium)

\begin{tabular}{|c|c|c|c|c|c|c|c|c|c|c|}
\hline \multirow[t]{2}{*}{ Konsumsi } & $\mathrm{C}$ & IR & FP & $\begin{array}{l}\text { W } \\
P\end{array}$ & $\begin{array}{l}\mathrm{B} \\
\mathrm{T}\end{array}$ & WR & I & RfD & $\mathrm{HI}$ & \multirow{2}{*}{$\begin{array}{c}\text { Resil } \\
-\quad 0\end{array}$} \\
\hline & $\begin{array}{l}\mathrm{mg} / 1 \\
\text { iter }\end{array}$ & $\begin{array}{l}\text { liter/ } \\
\text { hari }\end{array}$ & $\begin{array}{c}\text { hari/ta } \\
\text { hun }\end{array}$ & $\begin{array}{l}\text { tah } \\
\text { un }\end{array}$ & $\begin{array}{l}\mathrm{K} \\
\mathrm{g}\end{array}$ & $\begin{array}{c}\mathrm{Har} \\
\mathrm{i} \\
\end{array}$ & $\begin{array}{c}\mathrm{mg} / \mathrm{kg}- \\
\text { hari }\end{array}$ & $\begin{array}{c}\mathrm{mg} / \mathrm{kg}- \\
\text { hari }\end{array}$ & $\begin{array}{c}\mathrm{mg} / \mathrm{kg}- \\
\text { hari }\end{array}$ & \\
\hline $\begin{array}{c}\text { Dewasa (BT } \\
=70 \mathrm{Kg})\end{array}$ & 1.74 & 2 & 365 & 30 & $\begin{array}{l}7 \\
0\end{array}$ & $\begin{array}{c}109 \\
50\end{array}$ & 0.050 & 0.005 & 9.943 & $\begin{array}{c}\text { Beres } \\
\text { iko }\end{array}$ \\
\hline $\begin{array}{c}\text { Dewasa }(\mathrm{BT} \\
=55 \mathrm{Kg})\end{array}$ & 1.74 & 2 & 365 & 30 & $\begin{array}{l}5 \\
5\end{array}$ & $\begin{array}{c}109 \\
50\end{array}$ & 0.063 & 0.005 & 12.655 & $\begin{array}{c}\text { Beres } \\
\text { iko }\end{array}$ \\
\hline Aanak -anak & 1.74 & 1 & 365 & 6 & $\begin{array}{l}1 \\
5\end{array}$ & $\begin{array}{c}219 \\
0\end{array}$ & 0.116 & 0.005 & 23.200 & $\begin{array}{c}\text { Beres } \\
\text { iko }\end{array}$ \\
\hline
\end{tabular}

Sumber: Hasil Analisa

Tabel 30. Perhitungan analisa Resiko Dengan Parameter $\mathrm{Ca}_{2}{ }^{+}$(Kalsium)

\begin{tabular}{|c|c|c|c|c|c|c|c|c|c|c|}
\hline \multirow[t]{2}{*}{ Konsumsi } & C & IR & FP & $\begin{array}{l}\mathrm{W} \\
\mathrm{P}\end{array}$ & $\begin{array}{l}\mathrm{B} \\
\mathrm{T}\end{array}$ & WR & I & RfD & HI & \multirow{2}{*}{$\begin{array}{c}\text { Resik } \\
0\end{array}$} \\
\hline & $\begin{array}{l}\mathrm{mg} / \mathrm{l} \\
\text { iter }\end{array}$ & $\begin{array}{l}\text { liter/ } \\
\text { hari }\end{array}$ & $\begin{array}{c}\text { hari/ta } \\
\text { hun }\end{array}$ & $\begin{array}{l}\text { tah } \\
\text { un }\end{array}$ & $\begin{array}{l}\mathrm{K} \\
\mathrm{g}\end{array}$ & $\begin{array}{c}\text { Har } \\
\mathrm{i}\end{array}$ & $\begin{array}{l}\mathrm{mg} / \mathrm{kg}- \\
\text { hari }\end{array}$ & $\begin{array}{c}\mathrm{mg} / \mathrm{kg}- \\
\text { hari }\end{array}$ & $\begin{array}{l}\mathrm{mg} / \mathrm{kg}- \\
\text { hari }\end{array}$ & \\
\hline $\begin{array}{c}\text { Dewasa (BT } \\
=70 \mathrm{Kg})\end{array}$ & $\begin{array}{c}32.6 \\
2\end{array}$ & 2 & 365 & 30 & $\begin{array}{l}7 \\
0 \\
\end{array}$ & $\begin{array}{c}109 \\
50 \\
\end{array}$ & 0.932 & 0.0006 & $\begin{array}{c}1553.3 \\
33 \\
\end{array}$ & $\begin{array}{c}\text { Beres } \\
\text { iko }\end{array}$ \\
\hline $\begin{array}{c}\text { Dewasa (BT } \\
=55 \mathrm{Kg})\end{array}$ & $\begin{array}{c}32.6 \\
2 \\
\end{array}$ & 2 & 365 & 30 & $\begin{array}{l}5 \\
5 \\
\end{array}$ & $\begin{array}{c}109 \\
50 \\
\end{array}$ & 1.186 & 0.0006 & $\begin{array}{c}1976.9 \\
70 \\
\end{array}$ & $\begin{array}{c}\text { Beres } \\
\text { iko }\end{array}$ \\
\hline Aanak -anak & $\begin{array}{c}32.6 \\
2\end{array}$ & 1 & 365 & 6 & $\begin{array}{l}1 \\
5\end{array}$ & $\begin{array}{c}219 \\
0\end{array}$ & 2.175 & 0.0006 & $\begin{array}{c}3624.4 \\
44\end{array}$ & $\begin{array}{c}\text { Beres } \\
\text { iko }\end{array}$ \\
\hline
\end{tabular}

Sumber : Hasil Analisa

Pada sumur 4, analisa evaluasi terhadap kontaminan pada parameter yang telah ditentukan, dapat disimpulkan seperti pada lokasi pengambilan sampel sebelumsebelumnya, bahwa untuk semua parameter terpilih mempunyai faktor resiko terhadap kesehatan, kecuali pada parameter Fe (Besi), yang jika dilihat pada tabel 28 kandungan $\mathrm{HI}$ (Hitung Indeks) dalam rumus $\mathrm{HI}=\mathrm{I} / \mathrm{RfD}$, yaitu kurang dari 1 dalam arti pada parameter ini tidak beresiko.

\section{Metode Diagram Pie}

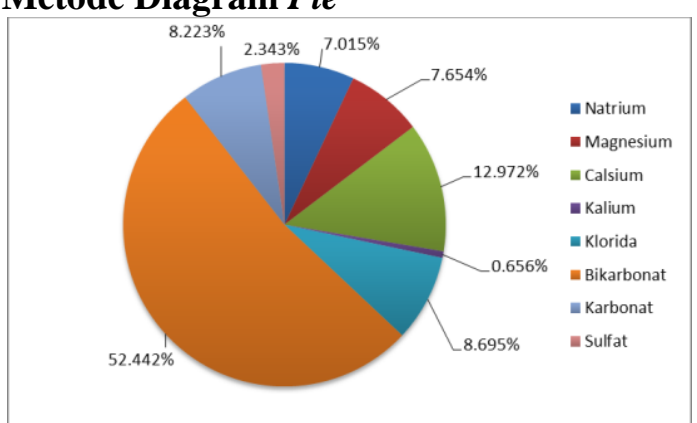

Gambar 4. Hasil Penggambaran Diagram Pie Sumur 1

Sumber: Hasil Analisa

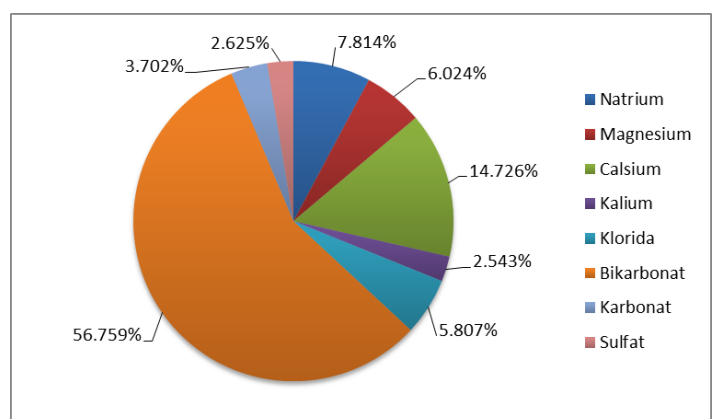

Gambar 5. Hasil Penggambaran Diagram Pie Sumur 2

Sumber: Hasil Analisa

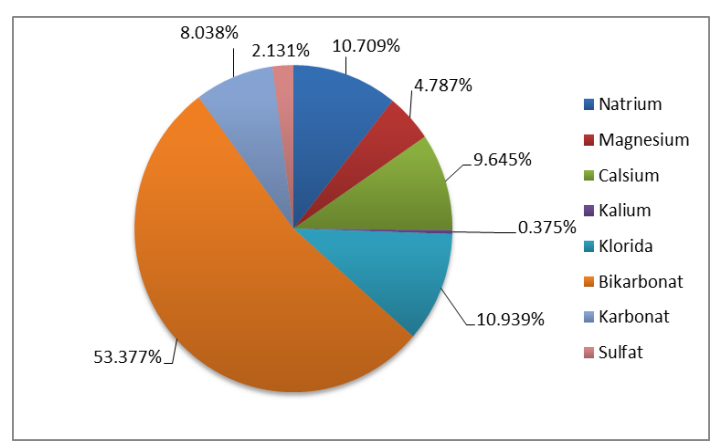

Gambar 6. Hasil Penggambaran Diagram Pie Sumur 3

Sumber: Hasil Analisa

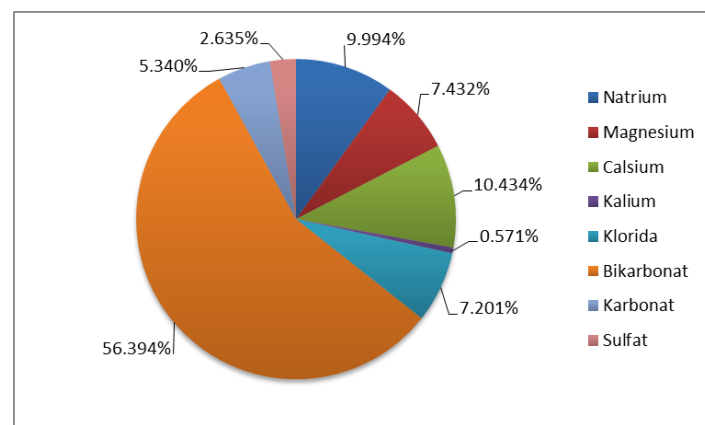

Gambar 7. Hasil Penggambaran Diagram Pie Sumur 4

Sumber: Hasil Analisa 
Metode Kurlov

Tabel. 31. Rekap Perhitungan Kurlov

\begin{tabular}{|c|c|c|c|c|c|c|c|c|c|}
\hline \multirow{2}{*}{\multicolumn{2}{|c|}{$\begin{array}{c}\text { Lokasi } \\
\text { Parameter Kimia }\end{array}$}} & \multicolumn{2}{|c|}{ Sumur 1} & \multicolumn{2}{|c|}{ Sumur 2} & \multicolumn{2}{|c|}{ Sumur 3} & \multicolumn{2}{|c|}{ Sumur 4} \\
\hline & & epj & \%ерj & epj & \%epj & epj & \%epj & epj & \%epj \\
\hline \multirow{4}{*}{ Kation } & $\mathrm{Na}^{+}$ & 1.124 & 24.791 & 1.298 & 25.120 & 1.522 & 41.970 & 1.562 & 35.151 \\
\hline & $\mathrm{Mg}^{2+}$ & 1.227 & 27.049 & 1.001 & 19.365 & 0.680 & 18.761 & 1.162 & 26.141 \\
\hline & $\mathrm{K}^{+}$ & 0 & 2.318 & 23 & 8.1 & 0.053 & 1.471 & 1.562 & 2.008 \\
\hline & $\mathrm{Ca}^{2+}$ & 2.079 & 45.841 & 2.447 & 47.338 & 1.371 & 37.798 & 1.631 & 36.700 \\
\hline \multicolumn{2}{|c|}{ Jumlah } & 535 & 100.000 & 5.168 & 100.000 & 3.626 & 100.000 & 5.917 & 100.000 \\
\hline \multicolumn{2}{|c|}{ Lokasi } & \multicolumn{2}{|c|}{ Sumur 1} & \multicolumn{2}{|c|}{ Sumur 2} & \multicolumn{2}{|c|}{ Sumur 3} & \multicolumn{2}{|c|}{ Sumur 4} \\
\hline \multicolumn{2}{|c|}{ Parameter Kimia } & epj & \%ерj & epj & \%ерj & epj & \%ерj & epj & \%ерj \\
\hline \multirow{4}{*}{ Anion } & $\mathrm{Cl}^{-}$ & 1.394 & 12.127 & 0.965 & 8.429 & 1.554 & 14.686 & 1.126 & 10.062 \\
\hline & $\mathrm{HCO}_{3}{ }^{-}$ & 8.405 & 73.138 & 9.430 & 82.388 & 7.585 & 71.662 & 8.815 & 78.796 \\
\hline & $\mathrm{CO}_{3}{ }^{2-}$ & 1.318 & 11.468 & 0.615 & 5.373 & 1.142 & 10.791 & 0.835 & 7.461 \\
\hline & $\mathrm{SO}_{4}{ }^{2-}$ & 0.375 & 3.267 & 0.436 & 3.810 & 0.303 & 2.861 & 0.412 & 3.681 \\
\hline \multicolumn{2}{|c|}{ Jumlah } & 11.492 & 100.000 & 11.446 & 100.000 & 10.584 & 100.000 & 11.187 & 100.000 \\
\hline \multicolumn{2}{|c|}{$\mathrm{pH}$} & \multicolumn{2}{|c|}{5.79} & \multicolumn{2}{|c|}{6.27} & \multicolumn{2}{|c|}{6.34} & \multicolumn{2}{|c|}{6.25} \\
\hline \multicolumn{2}{|c|}{ Kurlov } & \multicolumn{2}{|c|}{$\mathrm{HCO}_{3}{ }^{-}, \mathrm{Ca}^{2+}$} & \multicolumn{2}{|c|}{$\mathrm{HCO}_{3}{ }^{-}, \mathrm{Ca}^{2+}$} & \multicolumn{2}{|c|}{$\mathrm{HCO}_{3}{ }^{-}, \mathrm{Na}^{+}$} & \multicolumn{2}{|c|}{$\mathrm{HCO}_{3}{ }^{-}, \mathrm{Ca}^{2+}$} \\
\hline \multicolumn{2}{|c|}{ Tipe Air } & \multicolumn{2}{|c|}{$\begin{array}{c}\text { Kalsium } \\
\text { Bikarbonat }\end{array}$} & \multicolumn{2}{|c|}{$\begin{array}{c}\text { Kalsium } \\
\text { Bikarbonat }\end{array}$} & \multicolumn{2}{|c|}{$\begin{array}{c}\text { Natrium } \\
\text { Bikarbonat }\end{array}$} & \multicolumn{2}{|c|}{$\begin{array}{c}\text { Kalsium } \\
\text { Bikarbonat }\end{array}$} \\
\hline
\end{tabular}

Sumber :Hasil Analisa

\section{Hasil Rekapitulasi Interpretasi Metode}

- Diagram Pie: Kandungan nilai Karbon $\left(\mathrm{HCO}_{3}{ }^{-}\right)$, dan Kalsium $\left(\mathrm{Ca}_{2}^{+}\right)$lebih dominan.

- Klasifikasi Kurlov : Tipe penamaan kelas airnya adalah untuk sumur 1, 2, 4, Kalsium Bikarbonat $\left(\mathrm{HCO}_{3}^{-}, \mathrm{Ca}_{2}^{+}\right)$dan untuk sumur nomer 3 Natrium Bikarbonat $\left(\mathrm{HCO}_{3}{ }^{-}, \mathrm{Na}^{+}\right)$

Dari hasil yang didapatkan pada setiap metode, jika dihubungkan pada analisa resiko terhadap asupan kontaminan, perameter $\mathrm{Ca}$ (Kalsium) merupakan parameter yang beresiko terhadap kesehatan, dan juga merupakan parameter yang mendukung terjadinya kesadahan, jika kandungan unsur elekrolit tersebut digabungkan dengan mineral $\mathrm{HCO}_{3}{ }^{-}$(Karbonat). $\mathrm{Ca}\left(\mathrm{HCO}_{3}\right)^{2}$ kandungan unsur ini sangatlah berbahaya bagi tubuh karena dapat menimbulkan gangguan terhadap kesehatan terhadap oarang yang mengkonsumsi secara berlebihan.

\section{KESIMPULAN DAN SARAN Kesimpulan}

Dari hasi pengujian $\mathrm{Ph}$ (keasaman) di semua sumur memiliki rata-rata nilai 6 yang berarti air semua sumur bersifat asam, bahkan jika dilihat pada tabel 2, hasil Kandungan dari Laboratorium, pada sumur nomer 1 memiliki nilai 5,79 yang berarti keasaman lebih rendah dari sumur yang lain.
Hasil uji parameter fisik kekeruhan (NTU) pada sampel air lokasi studi menunjukan bahwa kandungan pada beberapa sumur mempunyai kandungan yang cukup tinggi melebihi kadar maksimum yang diperbolehkan terdapat pada sumur nomer 1 dan 3 . Untuk parameter fisik suhu $\left({ }^{\circ} \mathrm{C}\right)$ tidak menunjukan nilai yang tinggi melebihi kadar maksimum.

Berdasarkan peraturan mentri Peraturan Kementrian Kesehatan Nomer 492/Menkes /Per/IV/2010 tentang persyaratan kualitas air minum, untuk $\mathrm{pH}$ pada semua sumur tidak aman untuk dikonsumsi, untuk kekeruhan hanya pada sumur nomer 2 dan 4 memiliki yang aman untuk di konsumsi, sedangkan untuk suhu semua sumur memiki kadar yang normal untuk di konsumsi. Pada parameter Magnesium semua sumur memiliki status mutu tidak aman untuk dikonsumsi. Untuk parameter Besi sumur 1, dan 4 status mutu airnya aman tapi pada sumur nomer 2, dan 3 tidak aman untuk di konsumsi. Pada analisa resiko terhadap evaluasi asupan kontaminan yang masuk kedalam tubuh manusia hanya parameter besi $(\mathrm{Fe})$ yang tidak beresiko untuk dikonsumsi, sedangkan parameter lain seperti $\mathrm{Na}^{+}, \mathrm{Mg}^{2+}, \mathrm{Ca}^{2+}, \mathrm{K}^{+}, \mathrm{Cl}^{-}, \mathrm{HCO}_{3}{ }^{-}, \mathrm{CO}_{3}{ }^{2-}$ , $\mathrm{SO}_{4}{ }^{2-}$ menunjukan hasil beresiko apabila mengkonsumsi 2 l/hr dalam jangka waktu 30 tahun untuk dewasa sedangkan untuk anakanak kadar konsumsinya $1 \mathrm{l} / \mathrm{hr}$ dalam jangka waktu 6 tahun 
Karakteristik kimia air tanah dianalisis dengan menggunakan 3 metode yaitu metode Diagram Pie, Diagram Trilinier Piper dan Klasifikasi Kurlov. Dapat disimpulkan bahwa dari metode Diagram Pie kandungan nilai karbon $\left(\mathrm{HCO}_{3}{ }^{-}\right)$yang terdominan pada anion dan Kalsium $\left(\mathrm{Ca}_{2}^{+}\right)$yang dominan pada kation. Sedangkan pada Klasifikasi Kurlov kesimpulan tipe kelas airnya adalah lebih dominan Kalsium Bikarbonat, dari hasil analisa dengan metode tersebut di dapatkan senyawa kimiawi yang dapat di bentuk pada lokasi penelitian adalah Dimana sifat kimia ini menunjukkan tingkat karbon yang tinggi dikarenakan kandungan $\left(\mathrm{HCO}_{3}{ }^{-}\right)$pada daerah penelitian.

\section{Saran}

Untuk pengguna sumber daya air di lokasi penelitian di sarankan untuk mengolahnya terlebih dahulu sebelum dikonsumsi untuk air minum atau memanfaatkan PAM (Perusahaan Air Minum) yang ada di Desa Gamping Kecamatan Campurdatar kabupaten Tulungagung.

Diharapkan pemerintah meneliti sifat kimia dan fisik air tanah pada Desa Gamping Kecamatan Campurdarat Kabupaten Tulungagung secara berkala, agar dapat mengambil solusi lebih lanjut tentang bagaimana cara menurunkan kadar kandungan kimia yang beresiko tersebut.

Ketidaklengkapan atau kurangnya kadar unsur kimia maksumum tingkat keamanan pada air minum

Pada Peraturan Mentri Kesehatan Nomer 492/MENKES/Per/IV/2010 membuat peneliti susah menganalisa keamanan kelayakan kualitas air minum oleh karena itu, diharapkan pemerintah untuk menambahkan unsur-unsur kimia yang lain agar peneliti dapat menganalisa tingkat keamanan kelayakan kualitas air minum lebih lengkap.

\section{DAFTAR PUSTAKA}

Anonim. (2016). Panduan Penulisan Skripsi. Malang: UPT penerbitan Fakultas Teknik Universitas Brawijaya.

Anonim. (2008). Metode Pengambilan Contoh Air Tanah. Jakarta: Badan Standarisasi Nasional.

Anonim. (1991). Metode Pengambilan Contoh Kualitas Air. Jakarta: Badan Standarisasi Nasional.

Bower, H. (1978). Groundwater Hydrology. Inc. Tokyo: McGraw-Hill

Ermawan, R. P. (2017). Studi Efektifitas Filter Pejernih Air Tanah Menggunakan Media Zoelite, Karbon Aktif, Pasir, Silika, Dan Kerikil Untuk Mengurangi Kadar Parameter Pada Kualitas Air Minum. Skripsi. Tidak Dipublikasikan. Malang: Universitas Brawijaya

Kristanto, D. D. (2015). Analisis Karakteristik Sifat Kimia Air tanah Sumur Dangkal di kabupaten Situbondo Akibat Aliran Air Gunung Kawah Ijen. Skripsi. Tidak Dipublikasikan. Malang: Universitas Brawijaya

Notodarmojo, S. (2005) Pencemaran Tanah Dan Air Tanah. Bandung: Penerbit ITB.

Primasari, R. W. (2014). Kajian Sifat Kimia Air Tanah Dangkal Di Daerah Sekitar Lumpur Sidoarjo. Skripsi. Tidak Dipublikasikan. Malang: Universitas Brawijaya.

Sutrisno, T. (2010). Teknologi Penyediaan Air Bersih. Jakarta: PTRINEKA CIPTA.

Tood, D. K. (1980). Groundwater Hydrology. Toronto: John Wiley \& Sons, Inc.

Yuliani, E. (2014). Analisa Resiko Pencemaran Air . Malang: Naskah Modul Elektronik Universitas Brawijaya 